\title{
Lymphocyte expansion in bioreactors: upgrading adoptive cell therapy
}

\author{
Oscar Fabian Garcia-Aponte, Christoph Herwig (i) and Bence Kozma
}

\begin{abstract}
Bioreactors are essential tools for the development of efficient and high-quality cell therapy products. However, their application is far from full potential, holding several challenges when reconciling the complex biology of the cells to be expanded with the need for a manufacturing process that is able to control cell growth and functionality towards therapy affordability and opportunity. In this review, we discuss and compare current bioreactor technologies by performing a systematic analysis of the published data on automated lymphocyte expansion for adoptive cell therapy. We propose a set of requirements for bioreactor design and identify trends on the applicability of these technologies, highlighting the specific challenges and major advancements for each one of the current approaches of expansion along with the opportunities that lie in process intensification. We conclude on the necessity to develop targeted solutions specially tailored for the specific stimulation, supplementation and micro-environmental needs of lymphocytes' cultures, and the benefit of applying knowledge-based tools for process control and predictability.
\end{abstract}

Keywords: Adoptive cell therapy, ATMP, Bioreactor, Expansion, Lymphocyte, Rocking motion, Stirred reactor, Perfusion reactor, NK cell, T cell

\section{Background}

In the process of understanding cancer, clinical research has developed a resourceful toolbox of treatment options ever increasing in complexity. From surgery and radiation therapy, going through chemotherapy and biologics, we have arrived to the field of Cancer Immunotherapy [1], an approach that merges with the innovative area of Advanced Therapy Medicinal Products (ATMPs) to develop the specialty of Adoptive Cell Therapies (ACT).

This branch of immunotherapy is defined as the intravenous administration of ex vivo expanded immune effector cells that are capable of selective cytotoxicity. It exploits the immune system's ability to distinguish between pathologic and healthy tissue [2,3]. ACT has been

\footnotetext{
* Correspondence: christoph.herwig@tuwien.ac.at

Research Area Biochemical Engineering, Institute of Chemical, Environmental and Bioscience Engineering, TU Wien, Gumpendorferstraße 1a, 1060 Vienna, Austria
}

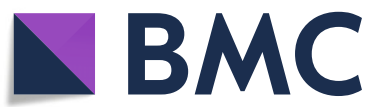

(c) The Author(s). 2021 Open Access This article is licensed under a Creative Commons Attribution 4.0 International License, which permits use, sharing, adaptation, distribution and reproduction in any medium or format, as long as you give appropriate credit to the original author(s) and the source, provide a link to the Creative Commons licence, and indicate if changes were made. The images or other third party material in this article are included in the article's Creative Commons licence, unless indicated otherwise in a credit line to the material. If material is not included in the article's Creative Commons licence and your intended use is not permitted by statutory regulation or exceeds the permitted use, you will need to obtain permission directly from the copyright holder. To view a copy of this licence, visit http://creativecommons.org/licenses/by/4.0/. The Creative Commons Public Domain Dedication waiver (http://creativecommons.org/publicdomain/zero/1.0/) applies to the data made available in this article, unless otherwise stated in a credit line to the data. hanced by means of gene modification because cells continue to function in vivo after they have been infused back into a patient [4]. ,To date, many cells have been used for ACT, including Lymphokine-Activated Killer (LAK) cells, Tumor-Infiltrating Lymphocytes (TILs), Cytotoxic T Lymphocytes (CTLs), Cytokine-Induced Killer (CIK) cells, $\gamma \delta \mathrm{T}$ cells, Regulatory T (TReg) cells, Natural Killer (NK) cells, engineered T cells (T-Cell Receptor (TCR T) cells and Chimeric Antigen Receptor (CAR) T cells) $[2,5,6]$.

Unfortunately, these cells remain as a limited therapeutic option that is only applied to a small number of patients. Partly because of significant knowledge gaps on their clinical effectiveness and cost/benefit ratio and a strong dependency on highly specialized methods, materials and equipment, therefore the number of products approved for commercialization is reduced [7, 8]. As the last decades saw progress in the understanding of 
lymphocyte biology and different companies are developing high throughput systems for ACT manufacturing [9], it is expected that this field will experience a quick clinical and technical expansion, that requires process intensification and innovative solutions from engineers. Hence, there will be a future push to technologize ACTs, from hospital-oriented to industrially relevant manufacture processes.

The manufacturing of an ACT product usually begins with a mixed lymphocyte population from a patient's biopsy, or from apheresed Peripheral Blood Mononuclear Cells (PBMCs) (Fig. 1). It can also be started by differentiating a cell subset from Hematopoietic Stem Cells (HSC) and lymphoid progenitors generally obtained from Umbilical Cord Blood (UCB). After cell acquisition, several workflows can be followed depending on the intended application. In upstream, most of the protocols include cell selection, enrichment, purification, activation, stimulation, gene modification and expansion, while downstream processes include pooling, further enrichment, formulation and cryopreservation [10-13]. Independently from the workflow, and because ACT doses composed of high cell numbers generally produce more desirable therapeutic outcome [14, 15], the cell expansion process is a common factor in any ACT protocol, being subjected to the greatest research efforts and the most significant body of user experience [16].
Expansion's ubiquity highlights its importance for ACT's optimization, relying on the application of Quality by Design (QbD) principles for sound bioprocess understanding. However, optimizing for a process focused only on high cell output could narrow the Critical Quality Attributes (CQAs) down to the productivity issue. In that sense, ACT would not benefit from an integrative clinical view, able to compensate for regulatory and engineering constraints [17] in a broader context that considers yield, cell purity and product functionality.

The aim of this review is to give a comparative overview of lymphocyte expansion in bioreactors, assessing their ability to generate sufficient, functional and correctly differentiated cell populations, with considerations to process flexibility, controllability and scale. We explore the manufacturing of lymphocytes primarily from PBMCs and biopsies, summarizing the outcomes from the diverse expansion processes but taking the comparability issues arising from the wide range of stimulation and supplementation strategies into the picture, apart from the selected bioreactor technology. Lymphocyte manufacturing from stem cells is excluded from this review as it adds an extra layer of complexity to the comparison exercise. We first provide a context on the general culturing requirements for lymphocytes, later discussing the challenges of transitioning to technologized manufacturing. Given that context, a set of

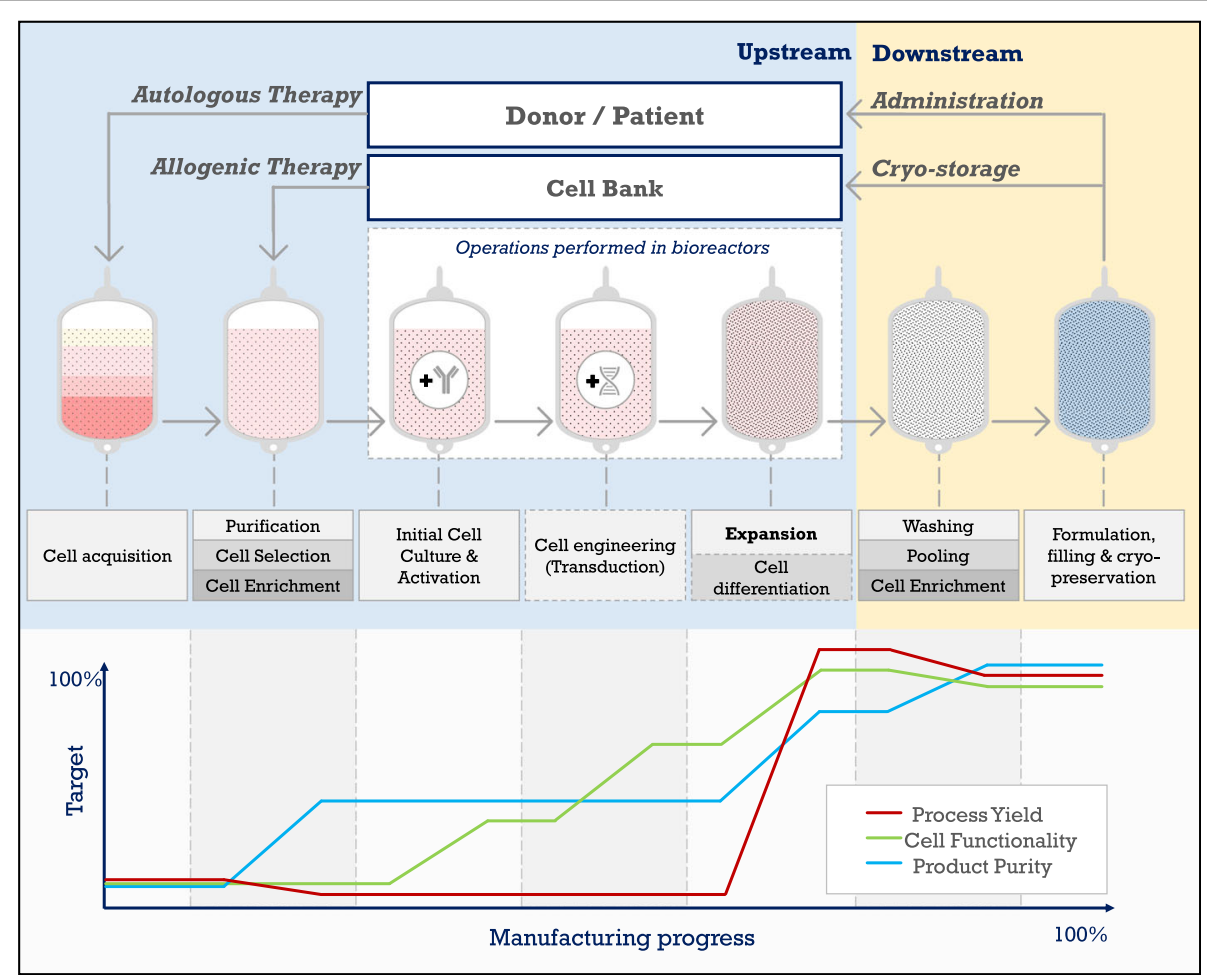

Fig. 1 General upstream and downstream steps of a cell therapy product from autologous or allogenic source. The graph shows the contribution of the different unit operations to final cell yield (red), functionality (green) and purity (blue). This review focuses on the expansion process 
requirements for bioreactor design and comparison for allogenic and autologous ACT is presented. We then review and categorize the available bioreactor technologies based on published results on process yield, cell purity and product functionality. Finally, we propose further knowledge intensive approaches that could be useful to take advantage of the data intensive environment that bioreactors bring to the field of ACT.

\section{The complexity of lymphocyte expansion}

Compared to small molecules and biologics, living cells are much more complex: they sense their surroundings, react to their environment and express varied and adjustable behaviors [18]. Furthermore, they have some unique features [19], including the ability to specifically distinguish, bind and kill abnormally growing cells by selectively switching metabolic pathways to enhance the production of cytotoxic substances [20]. Because of this complex biological setting, any small change in the culture environment may result in the alteration of product quality [21], a concept that acquires a greater dimension, as it becomes associated with information on cell state, phenotype, functionality and identity [22].

The unpredictable behavior of lymphocytes during culture causes noticeable variations in expansion rates amid manufacturing [23]. This inherent variability hinders any comparison between expansion protocols in order to conclude and organize best practices. At the core of this issue relies donor heterogeneity as differences related to age, gender, health issues or ethnicity are frequent [24]. Donor variability is also linked to process performance and lymphocyte sensitivity to process parameters [25]. Modeling for process predictability, associated with a thorough characterization of raw materials to compensate for source's variability can improve process understanding, accelerating the establishment of new cellular therapies [14]. To make it even more complex, lymphocytes can tune their communication with the environment by modifying their receptor/ligand repertoire, changing cellular sensitiveness to external substances and surfaces [19]. These aspects often generate an undesired outcome: when subjected to extensive cultivation, cells are prone to develop phenotypic changes (e.g. differentiation, senescence or immunogenicity) or genetic changes (e.g. mutations, gene deletions or chromosomal aberrations) that can severely undermine their safety and efficacy profiles. Therefore, higher yield due to prolonged expansion often correlates with the selection of more proliferative cell subpopulations, which can be less efficient for their designed function [14].

Additionally, immune cells must be stimulated by carefully integrating selection and activation steps during the expansion process. There are several technologies available for the activation of immune cells, including cell-based activation, bead-based activation, and antibody-based activation. Antigen Presenting Cells (APCs), as cell-based activators, are endogenous agents that provide an in vivo-like stimulation but they are expensive to use in a GMP environment, difficult to remove from the final cell population, variable in their potential to induce activation and may be scarce when isolated from donor samples [11]. Traditionally, immune cell expansion has also relied on the supplementation with animal or human serum. However, the use of serum may generate safety risks of infusion and increases process variability due to batch-to-batch differences [11, 26, 27]. Besides antigen-induced activation, stimulation with cytokines is another factor that influences the composition, quality and phenotype of the final cell product. T cells are generally produced by IL-2, IL-7 and/or IL-15 stimulation [28], while most current NK cell expansion protocols include the use of IL-2 and IL-15 [29, 30]. Complex, precisely scheduled cytokine cocktails for culture stimulation can also be used under certain expansion protocols.

Through the usage of these stimulation agents, the expanded cells undergo frequent metabolic changes. They can move into quiescence or active status, start the division cycle, enter apoptosis or differentiate. Knowing what process is triggered in which cells is important, yet most expansion results just consider the overall expansion rate of a given subset of cells. Furthermore, metabolism is not only relevant as a descriptor of cell growth. There is a growing body of evidence that shows immune cell metabolism to be essential to cell functionality. For example, glycolysis and oxidative metabolism have been shown to modulate classical anti-tumor effector functions of NK cells [31]. Thus, positive and negative modulation of certain metabolic triggers could be used to control ex vivo expansion and direct cell functionality. Amino acid modulation is another tool that may enhance cell expansion, because some of them, such as glutamine, arginine and tryptophan, have been found to influence lymphocyte proliferation [32].

Summarizing, lymphocytes could be portrayed as delicate cells requiring very meticulous culturing. Their behavior can be unpredictable to some extent, because of a combination of factors that include donor and cell population heterogeneity, frequent metabolic changes, high sensitivity to culture environment and strong dependency on an accurate stimulation strategy that mimics typical in vivo conditions. This complexity demands an expansion process that is sensitive and flexible enough to compensate for variability. This is offered by various bioreactor systems that were proven to be applied for lymphoid cultures. 


\section{From static cultures to intensified processes}

Despite of the tight control needed for efficient ACT manufacturing, immune cells are still frequently expanded in static systems equipped with limited monitoring capacity $[10,19,23]$. These platforms (plates, flasks and bags) depend on incubators and are restricted to a batch-and-split mode which periodically divides and refills the culture with medium to cope with the cells' metabolic activity and stimulation requirements, therefore these cultures are highly susceptible to contamination as multiple open vessels are needed to create a single product [33]. Furthermore, the medium renewal cycles cause frequent nutrient and metabolite fluctuations that may trigger high phenotypical variability [19]. As a result, ACT cells are still manufactured through processes and methods that have been characterized as "archaic, scarcely controlled and incomparable" [34]. Because of their simplicity, cell therapy companies may initiate clinical trials using static systems, requiring further assessment as key differences in parameters such as shear stress, culture conditions, and cell-to-cell interactions may cause a divergent biological profile as the cells are moved to a bigger scale dynamic set-up [35].

Quality testing, which includes complex functionality assays, should be carried in a timely manner, as ACT products are generally used or preserved briefly after production, increasing the risk of uncertainty and therapeutic mistakes [36]. This implies that Process Analytical Technology (PAT) alone is not able to provide robust information to address most quality questions. Because of that, discrete in-process characterization of cell status during manufacture is generally out of phase with properties continuously monitored using PAT tools, which are inferential in nature (e.g. DO, $\mathrm{pH}$, glucose consumption or cell density) [37]. However, our comprehension of cell status, including metabolomics, clonogenicity and cell cycle regulation is significantly improving [38].

Most of the bioreactors used for the cultivation of therapeutic cells originate from vessels and technology created for upstreaming bacteria or yeast [14]. However, it is important to note that these systems do not focus on cell integrity and functionality but on maximizing yield, thus requiring refitting to face the challenge of generating a healthy and functional cellular product [38]. Bioreactors allow process scale up with high standardization and reproducibility, while enabling the evaluation of the influence of process parameters on culture performance [39]. In the same way, process intensification through the implementation of mechanistic modeling and PAT tools, along with the use of automated culturing techniques, facilitates to reach better control over cell expansion [14] (Fig. 2).

A bioreactor's capability to monitor and control critical process parameters is a highly valuable characteristic yet to be optimally explored with lymphocyte cultures. To profit on these abilities, several bioreactor designs were already tested for lymphocyte culturing. These different bioreactor configurations (Fig. 2) are generally suitable for a specific field of ACT (either allogenic or autologous applications). However, as the cultured cells have in principle the same needs, a general set of requirements towards maximizing bioreactor capabilities can be formulated, guiding the transition from static cultures to intensified processes.

\section{Requirements of bioreactors for lymphocyte culture}

Although every cell therapy process has unique elements, it is not practical to design specialized devices for each specific product. Instead, ACT products should be grouped on shared process characteristics, defining strategies and technologies that fit better for each category as a whole [40]. In that regard, ACT can be performed using two general principles: autologous and allogenic. In the autologous setting, a batch is individually produced from a patient's biopsy, isolating and culturing the cell population of interest. In the allogenic workflow, cell source is a universal donor platform with highly expandable cells that have similar scale requirements as the manufacturing of cell derived proteins and the cell product may target multiple patients [25]. Process-wise, increasing vessel scale and ensuring culture performance (scale-up) is related to allogeneic approaches, while parallelizing several independent units (scale-out) is generally the goal in optimizing autologous therapy [22]. An autologous batch size is not expected to exceed more than a few liters volume, because of the limited amount of starting material and the time sensitivity of the cells to retain their functionality. Thus, scaling up autologous is not useful and scaling out for multiple batches still requires a thorough assessment of technical capacities [35]. This delicate setting for autologous cell therapy drives bioprocess development towards automation [11, 25], as the ideal autologous platform should compensate for the effects of varying culture conditions on CQA's performance [40]. The allogenic set up, on the other hand, requires appropriate inoculation levels with minimal seed adaptation to maximize the expansion outcome. Therefore, the possibility of having a set of vessels geometrically and dynamically comparable is highly relevant [41]. In the same way, achieving consistent process reproducibility is necessary for a standardized and safe allogenic platform, thus, allogenic bioprocess development is mostly driven towards process control than workflow automation. To harness a bioreactor's full potential, its design and application should be fitted to the challenges of cultivating lymphocytes and the supplements necessary for their growth. These are, in the view 


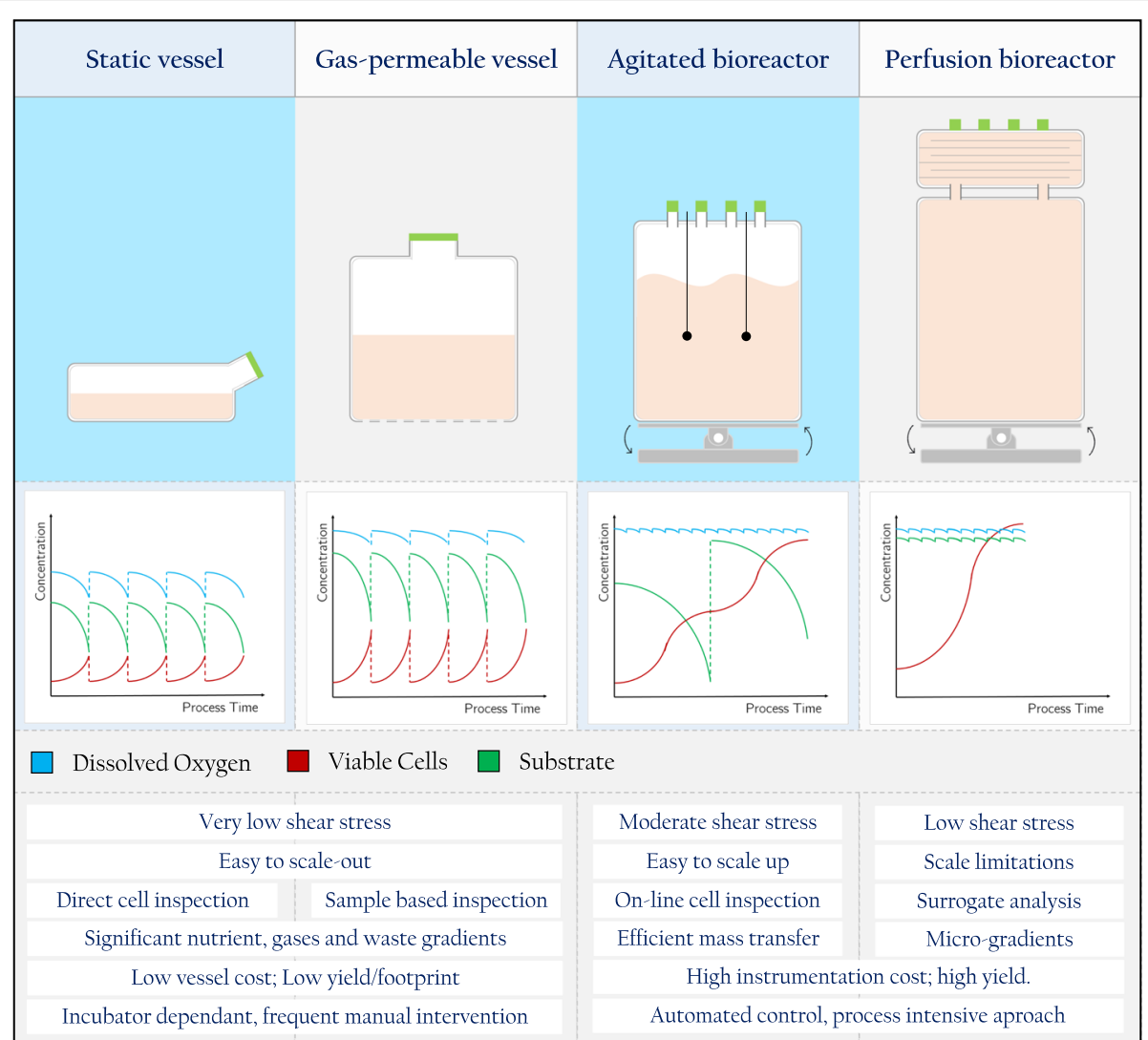

Fig. 2 Main characteristics of static and dynamic culture vessels and their influence on process variability. Typical trends of viable cell density (red line), nutrient concentration (green line) and dissolved oxygen (blue line) for each culture vessel type

of the authors, and based on previous frameworks of requirements $[14,19,25,34,35,42]$, the main standards to be fulfilled by a culturing platform for ACT.

\section{Suitable vessel size and scalability}

Cell-based therapies often require the application of vast quantities of cells $\left(10^{8}-10^{10}\right)$ to patients therefore the space required for their growth is a practical limitation. Assuming a culture density of $10^{6}$ to $10^{7}$ cells $/ \mathrm{mL}$ (a high value for ACT), it would demand a volume starting from few milliliters up to tens of liters during culture [43]. The available bioreactor scale must be flexible enough to fully accommodate the range of cell growth across all feasible batches, and to compensate for the expected potential growth variability from the source [25]. To achieve this, ultra-high cell density cultures or an industrial scale production that is able to maintain uniform culture conditions are required [39]. Some current expansion processes include a preliminary stage where cells are activated and rapidly multiplied in static systems, generating enough cells for bioreactor inoculation. However, enough bioreactor space for the actual expansion is still necessary.

\section{GMP compliance}

To avoid cross contamination (between different batches or patients) and microbiological contamination, closed systems (bags, expansion sets, flasks), incubators and hoods should be used [36]. Bioreactors should guarantee sterility by keeping a closed system [19]. Each manipulation step (e.g. inoculation, activation, transduction, media changes, stimulation, sampling, washing) creates a risk for error and contamination that may lead to a failed run [36]. For that purpose, single-use, closed, disposable cell production "kits" may represent a desired design strategy for patient-specific cell therapy manufacturing protocols [44], particularly if such kits can be designed for simplicity [43].

\section{Process control}

Once the specific requirements for the cells being expanded have been defined, process parameters such as temperature, shear stress, dissolved oxygen (DO) and $\mathrm{CO}_{2}$ and environmental variables like osmolality and $\mathrm{pH}$ must be kept at optimal values [14]. .Extensive, online process monitoring and integrated control is required for adaptation to process changes [45]. $\mathrm{DO}$ and $\mathrm{pH}$ of the medium are typically held 
constant to provide a consistent environment supporting optimal cell expansion. DO and $\mathrm{pH}$ signals, are valuable for assessing the status of the expansion medium and cell proliferation, triggering a proportional feeding strategy [41], although this is a fairly limited approach. Some technologies that should be considered for ACT process monitoring and control are included in Table 1. The final goal of process monitoring should be to find descriptors that can give information about the influence of batch-to-batch or donor-to-donor variability on the expansion process [58]. The best approach for process control development would be to use PAT data to facilitate process related decisions in real-time, or even predictively. This can include decision points for transduction, perfusion initiation, harvest point, or even quality control release based on minimum viability or endotoxin level. Ideally, such technologies would evolve to measure surface markers expression of key phenotypic markers.

\section{Handling of shear stress}

Ex vivo expansion of all immune cell types should avoid mechanical stress by chaotic, inhomogeneous medium dynamics [19]. It has been long established that animal cells are sensitive to shear, which, above certain levels, compromises their viability. Besides the direct effect that mechanical forces can exert on a cell membrane's integrity, animal cells are adapted to the environment of each tissue, evolving sensitive mechanisms for detecting shear changes. To develop an acceptable understanding of how these forces influence cell behavior, it is necessary to recreate similar level of shear forces than found in the body within a bioreactor, allowing for a detailed characterization and control of the mechanotransduction process [59] and the direct effects of shear on the cells. Importantly, agitation must be designed to manage not only shear exposure of cells, but also the efficiency of mass transfer, suspension of cells and avoidance of heterogeneities that may cause cell inconsistencies [25].

\section{Representative sampling}

The designed bioreactor process should stay out of any artificial deleterious influences on cell integrity by passaging and reseeding the cells, as it may decrease total yield [19]. Sampling and harvesting of cells, medium, or both should be also designed with simplicity in mind. Taking samples has certain drawbacks that need to be mitigated [35]: to get a representative bioreactor sample, a significant volume should be drawn, which can impact on yield, especially if multiple small scale vessels are used for the cell expansion. Repeated sampling can also increase the risk of contaminating the bioreactor. Issues that need to be resolved in such cell therapy process development platforms include deciding on the amount of cells needed to reflect heterogeneity and the usage of live cell-based image analysis and "lab-on-chip" strategies [43].

\section{Stimulation and supplementation}

Media changes in bioreactors are usually done by nutrient addition, or by total or partial media replacement, or by perfusion. If a cell culture produces non-damaging levels of waste products, concentrated levels of nutrients can be added over time to feed the growing culture. Inevitably, waste metabolites such as lactate and ammonia start to accumulate, and either media replacement or perfusion is required. Perfusion, in which fresh media is gradually fed and old media is removed while the cells are retained, is the ideal way to intervene and still maintain a stable environment for cell therapy [35]. It also should be noted that cell exhaustion can be induced by current activation methods, which generally also demand careful operator attention [32]. Because of that, precise optimization of the feeding of nutrients and cell activators/stimulants is needed, being able to precisely supply them into the culturing medium, allowing for different feeding profiles.

Table 1 Advanced process monitoring tools for ACT

\begin{tabular}{|c|c|c|c|}
\hline Tool & Application & Type & Ref. \\
\hline \multirow[t]{3}{*}{ Raman spectroscopy } & Metabolite monitoring (glucose, lactate, amino acids). & On-line & {$[46]$} \\
\hline & Total Cell Concentration. & On-line & {$[46]$} \\
\hline & Cell identity determination (phenotype \& activation). & At-line & {$[47,48]$} \\
\hline \multirow[t]{2}{*}{ Sequential injection capillary electrophoresis } & Metabolite monitoring (glucose, lactate, amino acids). & At-line & {$[49]$} \\
\hline & Cell concentration. & At-line & {$[49]$} \\
\hline FT-IR spectroscopy & Glucose monitoring. & On-line & {$[50]$} \\
\hline Electrical impedance & Cell-mediated cytotoxicity and cell adhesion. & At-line & {$[51-53]$} \\
\hline Biosensors for acidification measurement & Metabolite monitoring (lactate). & On-line & {$[54]$} \\
\hline Biosensors - optical & Cytokine quantification. & Potential & {$[55,56]$} \\
\hline Gas chromatography-mass spectrometry & Volatile organic compound (VOC) emissions profiling - metabolic monitoring. & On-line & {$[57]$} \\
\hline
\end{tabular}




\section{Gas transfer}

Gas transfer happens passively in static systems, which limits oxygen availability in high volume vessels, as the diffusive flux of a gas is inversely proportional to the thickness of the liquid that needs to be permeated, according to Fick's law and the McMurtrey model of oxygen diffusion [60]. Oxygen transfer may be limited in non-perfused bioreactors because low agitation rates are required to minimize shear stress on the lymphocytes and headspace aeration is also generally preferred for the same reasons. This, on the long run, may hinder the final expansion output of the system [41]. .Oxygen can be supplied to a bioreactor either via the headspace or via a sparger which disperses gas into the medium, however, sparging has been shown to be possibly detrimental for immune cell growth [61]. The physiological oxygen concentration is usually lower than the atmospheric. Because of that, establishing culturing protocols that resembles in vivo oxygenation conditions may improve expansion yield and cell functionality [22]. Similarly, the use of $\mathrm{CO}_{2}$ levels representative of the biological fluctuation threshold could also be beneficial of the process outcome. It must be noted that reduced oxygen tension results in reduced human $\mathrm{T}$ cell proliferation, increased intracellular oxidative damage and susceptibility to apoptosis upon activation, highlighting the importance of controlling oxygen levels in culture [62].

\section{Physiological congruency}

There is no ideal bioreactor that suits all purposes for all cells, but it should be able to replicate in vitro many of the conditions experienced in vivo, therefore it should allow for experimental testing, mechanical conditioning and monitoring of living cells in dynamic conditions [59]. In a close physiological remembrance, immune cells cultured in bioreactors often require APCs for stimulation, three-dimensional culturing, controlled cell-cell contact and undisturbed local microenvironments [25]. These needs should be taken into consideration during the design of suitable devices, starting from the fact that hematopoietic cells do not require a surface to grow, being anchorage independent [63]. It is true that cells can be adapted to a specific bioreactor design as a replacement to engineering the bioreactor itself, but it must be noted that this approach may not be available to most cell therapies, as cells may become senescent after a certain amount of doublings [25]. It should also be noted that some cells may need to be in extensive contact with each other, such as TILs [64] and $\mathrm{T}$ cells $[65,66]$, some of them also tend to form aggregates that must be controlled for optimal growth [67], usually by mechanical disruption of the clusters.
Different reactor configurations may fulfill these requirements to a varying extent. Given this framework, in the next chapter we explore the currently available options and highlight the most relevant characteristics that stand out from comparison.

\section{Comparison of currently available act bioreactor technologies}

During the 1980s, the foundational protocols [68-71] for TILs and LAK therapies were established to be carried out in plates, flasks, bags and roller bottles [72]. At the same time, several attempts of culturing lymphocytes for cytokine production in stirred reactors were being performed [73-77]. It was Knazek [78], Alter [79] and Tanji [80] who in the late 1980s performed the first bioreactor runs intended for cell therapy, using a hollow fiber perfusion system. In the 1990s, the use of the hollow fiber technology increased significantly, while stirred reactors were begun to be used for NK cell ACT applications [81] and the rotating wall bioreactor was introduced as a low shear device [82]. Stirred reactors continued into the 2000s as a solely experimental platform, while the rotating wall technology was not used in clinical applications, focused exclusively in microgravity studies [83-88]. The late 2000s have seen in the usage of the hollow fiber reactor a relative decline compared to the rise in the application of the static culturing GRex device (Wilson Wolf Manufacturing, Saint Paul, $\mathrm{MN}$ ) and the dynamic culturing rocking motion reactor. Both were quickly adopted into clinical practice, stirring the debate of high throughput static vs. dynamic lymphoid cell culturing. In the late 2010s, the hollow fiber reactor returned to wider usage thanks to the Quantum System (Terumo BCT, Tokyo, Japan), and a renewed interest in stirred reactors has been perceived from recent publications $[89,90]$. The late 2010s also saw the introduction of the Z RP platform [91] (ZellWerk $\mathrm{GmBH}$, Oberkrämer, Germany) and the Prodigy system [92] (Miltenyi Biotec, Bergish Gladbach, Germany). The latter is an integrated autologous-targeted platform that, despite of its novelty, has been extensively used. There is also high expectation on the Cocoon system [42] (Lonza, Basel, Switzerland) and rotating wheel reactors [11], both announced to be capable of lymphoid cell culturing. Given this historical background, the literature review presented here is based on 117 publications fulfilling the eligibility criteria, of which 73 contained detailed descriptions of the expansion protocols and results, categorized in Rocking motion reactors (16 results), Hollow fiber systems (18 results), Alternative perfusion systems (4 results), stirred reactors (10 results), G-rex-device-based processes (14 results) and Prodigy-system-based processes (11 results). From the 71 articles, 29 contained actual comparisons, mainly 
between a static protocol and a bioreactor culture with the same stimulation/supplementation strategy.

\section{Rocking motion bioreactors}

In the rocking motion system, a configurable swinging plate conveys a wave-like oscillation to the contents of a culture bag. The continuous agitation ensures proper oxygen transfer and medium homogeneity, which may provide a higher kLa than achievable with a stirred reactor, resulting in greater maximal cell densities under limited oxygen transfer conditions [93]. The agitation pattern is set by the rocking angle and rate, oscillation sequence and culture volume, which translates into a specific fluid flow, mixing time, residence time and oxygen transfer efficiency. This gentle agitation is considered to be a low shear method [94], which may cause lower cell stress even at increased rocking rates, improving nutrient and oxygen transfer efficiency and promoting cell growth without exerting detrimental mechanical conditions to the culture $[95,96]$. In contrast to a static system, where cells lay closely together, the continuous oscillation reduces the time that cells may spend in contact with each other, which may not be optimal for cultures requiring close cell-to-cell contact, such as TILs [64] and $T$ cells $[65,66]$, or adherent cells. Because of that, most cultures performed in this reactor include a static phase prior to the transfer to the rocking platform.

Current rocking motion devices can execute fully automated perfusion cycles, optimizing medium and supplements consumption thus, decreasing the overall process cost. Additionally, perfusion enables cells to be expanded above $10^{7}$ cells $/ \mathrm{mL}$, supporting high volume cultures to be carried out in a single bag with a significantly reduced volume (some bioreactor cultures need about half the amount of media to harvest $10^{10}$ cells, as compared to static conditions). Since bags are single use there is no need for cleaning validation, they provide a ready-to-use closed system decreasing turnaround time and resource requirements, significantly reducing costs in GMP operations [97]. Consequently, this platform is frequently used academically and industrially during phase 1 and 2 clinical trials [12]. The system also has some disadvantages, including a difficult transition from research scale to full scale GMP expansions. As it is necessary to purchase ancillary equipment additional to the bioreactor [64], it has been argued that rocking motion bioreactors are an ideal solution for scaling the manufacture up from $1 \mathrm{~L}$ to $1000 \mathrm{~L}$, but do not economically scale out from one patient to 1000 patients.

The rocking motion bioreactor has been successfully used for T, NK, NKT and TILs expansions (Table 2). Unfortunately, the results of these protocols are not easily comparable due to differences in cell stimulation strategy, media composition, starting material and process parameters. The rocking rate may differ according to the intended application, usually from 5 to 15 rocks per minute (RPM), and a perfusion strategy is generally used, starting from perfusion volume of 250 up to $4000 \mathrm{~mL} /$ day. The perfusion begins when a certain threshold is reached either by the decline or increase in metabolites such as glucose, glutamine, ammonia or lactate (especially TIL and T cell cultures) or by the increasing cell density. Once the perfusion is started, the $\mathrm{pH}$ and nutrients fluctuate within a narrow range with proven positive effects for TILs and $T$ cells $[64,100]$, while facilitating glycolysis and glutaminolysis.

Despite of the difficulties to compare the outcome of different studies, several authors have performed comparative analysis between static set-ups and the conditions provided by a rocking motion reactor (Table 3 ). In relation to expansion yield, although initially observed as detrimental for growth [94], it has been shown that rocking conditions do not induce significant changes in the total fold of the expansion in case of $T$ cells [66] and NK cells $[65,97,104]$, while boosting the growth of TILs [107, 108], DCs and CIK [97]. However, one study found no statistical difference in TIL expansion for static bags compared to a rocking motion bioreactor [64], possibly because of differences in the conditions of media exchange [108]. Similarly, non-perfused T cell cultures has been found to lose viability as low as $80 \%$ by the end of cultivation [100] because of critical deprivation of stimulants and metabolites. Contrary to stirred cultures, the use of shear protectant additives has been explored in rocking motion systems, where attempts to expand TIL in the absence of a surfactant (Pluronic F68), derived in significant cell damage and consequent decrease in cell count [64].

Although NK cells' expansion fold in a bioreactor is the same as in a static system, the proportion of NK cell subpopulations have consistently shown to be enriched under rocking conditions [65, 94, 97, 104]. Reactor-generated products contain fewer $\mathrm{CD} 3+\mathrm{T}$ cells and higher ratio of CD56 + CD3- NK cells than in static set-ups, perhaps because $\mathrm{T}$ cells could prefer non-dynamic conditions [65]. In the same way, clinical-scale activated CD56+ cells in a rocking motion reactor have similar phenotype and function as those derived from static cultures [105]. Unfortunately, the available studies are not clear about the effect of rocking on cell subpopulations in TIL cultures: the phenotype of TIL and genetically modified PBL expanded in static bags and in a rocking motion bioreactor have been found to differ [64]. However, under a different protocol, the numbers of $\mathrm{CD} 4+$ and CD8+ populations in a TIL culture were reported to be similar under dynamic and static conditions [107]. 


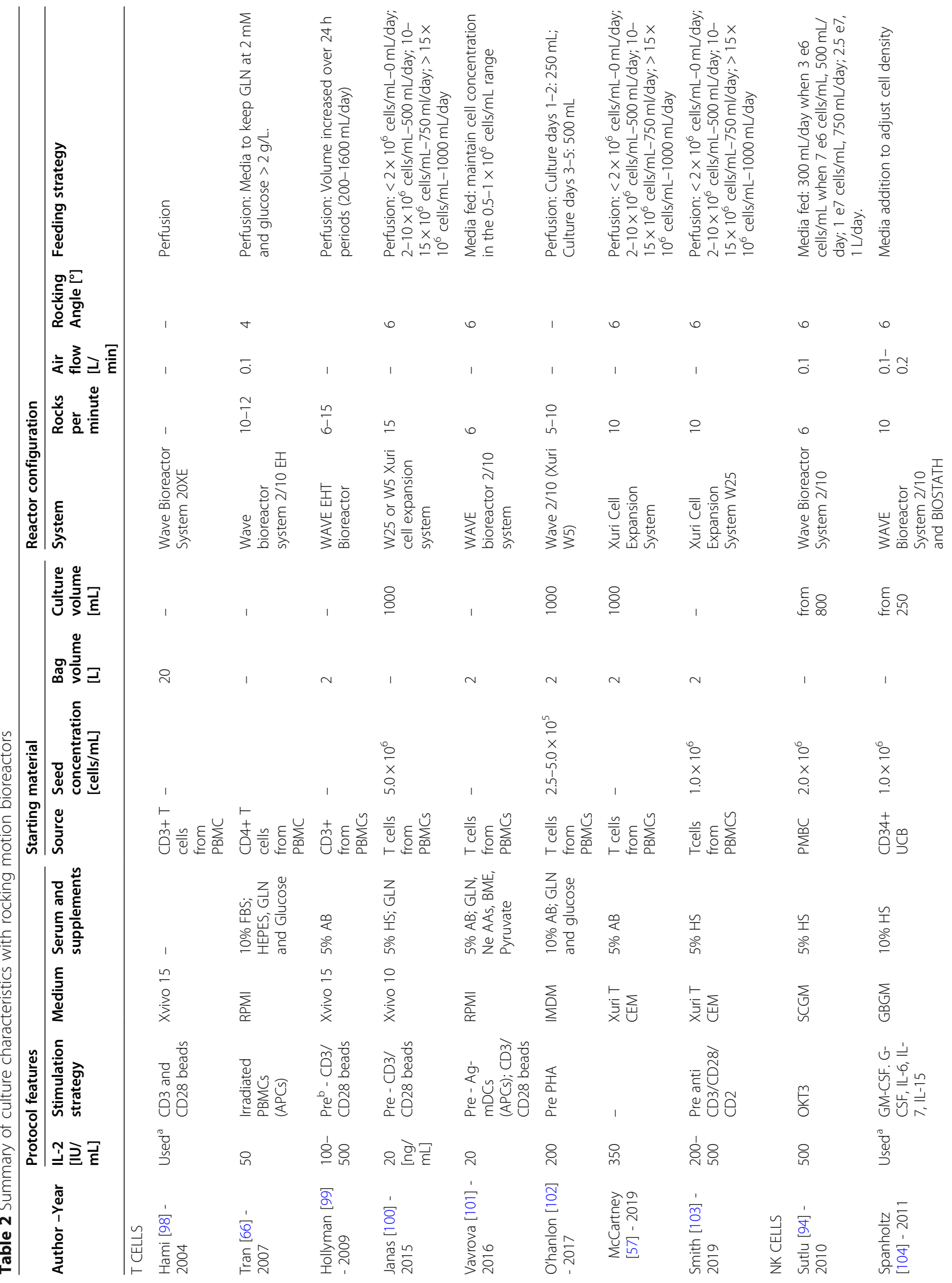




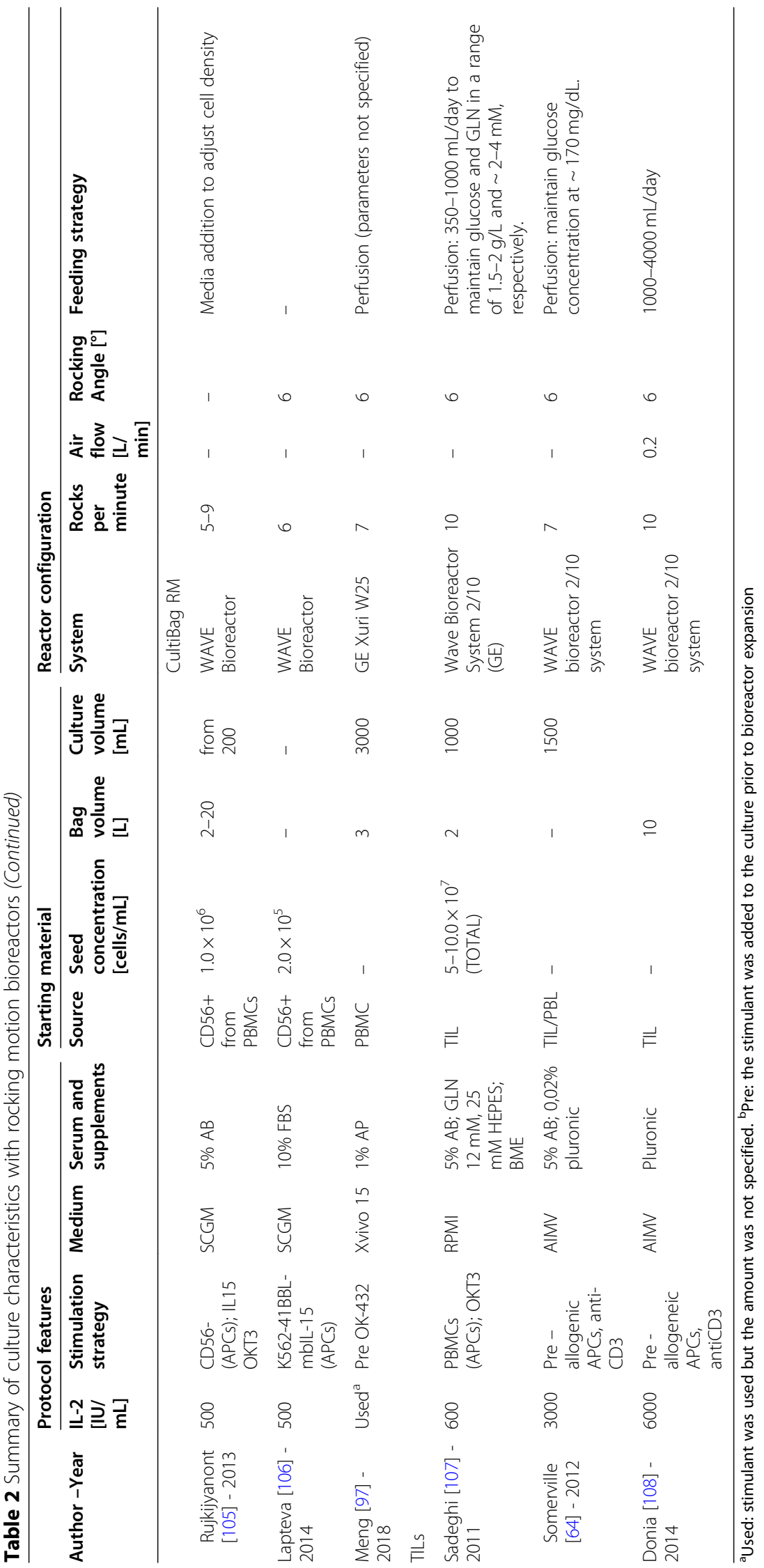


Table 3 Summary of the results of comparative studies about static and rocking motion cultures

\begin{tabular}{|c|c|c|c|c|c|c|c|}
\hline \multirow[b]{2}{*}{$\begin{array}{l}\text { Author - } \\
\text { Year }\end{array}$} & \multicolumn{4}{|c|}{ Expansion yield } & \multicolumn{2}{|l|}{ Purity } & \multirow[t]{2}{*}{ Functionality changes } \\
\hline & 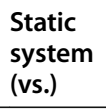 & $\begin{array}{l}\text { Static } \\
\text { fold }^{\mathrm{a}}\end{array}$ & $\begin{array}{l}\text { Reactor } \\
\text { fold }\end{array}$ & $\begin{array}{l}\text { Culture } \\
\text { days }\end{array}$ & Static & Reactor & \\
\hline \multicolumn{8}{|l|}{ T cells } \\
\hline $\begin{array}{l}\text { Tran [66] - } \\
2007\end{array}$ & Bags & $\begin{array}{l}247- \\
1340\end{array}$ & $200-800$ & 14 & - & $>98 \%$ CD4+ & $\begin{array}{l}\text { Markers of cell activation increased. No detectable Treg cells } \\
\text { produced. Cytokines are produced normally. }\end{array}$ \\
\hline \multicolumn{8}{|l|}{ NK cells } \\
\hline $\begin{array}{l}\text { Sutlu [94] - } \\
2010\end{array}$ & Bags & 530 & 77 & 20 & $31 \%$ NK & $\begin{array}{l}38 \% \text { NK; } \\
14 \% \text { NKT }\end{array}$ & $\begin{array}{l}\text { Degranulation and cytotoxic activity are greater in bioreactor } \\
\text { cultures. }\end{array}$ \\
\hline $\begin{array}{l}\text { Spanholtz } \\
\text { [104] - } \\
2011\end{array}$ & Bags & $\begin{array}{l}759- \\
1770\end{array}$ & $\begin{array}{l}1435- \\
2657\end{array}$ & 42 & $\begin{array}{l}71 \pm 9 \% \\
\text { CD56+ } \\
\text { CD3- }\end{array}$ & $\begin{array}{l}92 \% \pm 2 \% \\
\text { CD56 + } \\
\text { CD3- }\end{array}$ & $\begin{array}{l}\text { Higher expression of activating receptors in bioreactor cultures } \\
27 \% \text { degranulation in reactor vs } 14-18 \% \text { in static cultures }\end{array}$ \\
\hline $\begin{array}{l}\text { Lapteva } \\
{[65]-2014}\end{array}$ & G-rex & \multicolumn{2}{|c|}{ No difference } & 9 & \multicolumn{2}{|c|}{$\begin{array}{l}\text { Fewer } C D 3+T \text { and a } \\
\text { higher } C D 56+C D 3-N K \\
\text { cells in reactor culture }\end{array}$} & Potency is similar (phenotype and in cytotoxicity assays) \\
\hline $\begin{array}{l}\text { Meng [97] } \\
-2018\end{array}$ & Bags & \multicolumn{2}{|c|}{ No difference } & 15 & \multicolumn{2}{|c|}{$\begin{array}{l}\text { Reactor improves the } \\
\text { percentage of NK cells }\end{array}$} & $\begin{array}{l}\text { There is no significant modulation of the cells' secretome. } \\
\text { Cytotoxicity is significantly higher for bioreactor cultures. }\end{array}$ \\
\hline \multicolumn{8}{|l|}{ TIL } \\
\hline $\begin{array}{l}\text { Sadeghi } \\
{[107]-} \\
2011\end{array}$ & Bags & $72 \pm 11$ & $\begin{array}{l}228.8 \pm \\
17.1\end{array}$ & 14 & \multicolumn{2}{|c|}{$\begin{array}{l}\text { No difference in CD8+ } \\
\text { and CD4+ percentage }\end{array}$} & No difference in Phenotype \\
\hline $\begin{array}{l}\text { Somerville } \\
\text { [64] -2012 }\end{array}$ & Bags & $\begin{array}{l}1259 \pm \\
137\end{array}$ & $\begin{array}{l}1130 \pm \\
127\end{array}$ & 14 & \multicolumn{2}{|c|}{$\begin{array}{l}\text { Lower CD8 and higher } \\
\text { CD4 in reactor }\end{array}$} & $\begin{array}{l}\text { Increased IFN- } \gamma \text { release to cognate peptide in reactor culture } \\
\text { Significant phenotype differences }\end{array}$ \\
\hline $\begin{array}{l}\text { Donia } \\
{[108]-} \\
2014\end{array}$ & Bags & $\begin{array}{l}1433 \pm \\
887\end{array}$ & $\begin{array}{l}5576 \pm \\
1677\end{array}$ & 14 & - & $>97 \%$ CD3+ & - \\
\hline
\end{tabular}

${ }^{\mathrm{a}}$ Fold $=$ Harvested cells $/$ Seeded cells

In addition to the improvement of the proportion of target cell subpopulation, the functionality of NK cells expanded in rocking motion bioreactors has been found superior than in static systems. Cells cultivated in bioreactors show higher expression of activating receptors such as CD314 (NKG2D) and NCRs, which correlates with a higher degranulation capacity of bioreactor-expanded NK cells (27\%) towards K562 cells compared to the $14-18 \%$ reached by NK cells in static bag cultures [104]. This higher degranulation profile was also found in a different study [94], as the consequential increase in cytotoxicity [97]. $\mathrm{T}$ cell cultures in rocking motion bioreactors have shown increased expression of cell activation markers as compared to pre-cultures [66].

Because of the versatility and successful application of the rocking motion reactor, several studies have been performed using this platform (Table 4). There have been pre-clinical and clinical assays using the rocking motion technology for chronic lymphocytic leukemia [98, 99], metastatic melanoma $[109,110]$ and prostate cancer [101]. It has also been successfully used to introduce NMR markers during the expansion process [102].

In regard to on-line monitoring and control, biocapacitance probes have been successfully integrated into bioreactor bags, and most rocking reactors collect data from single-use DO and $\mathrm{pH}$ probes, which can be used, with some limitations, as surrogate measures of VCD to decide on perfusion and DO control, eventually decreasing the frequency of sampling. Alternatively, differential digital holography imaging devices allows for the assessment of cell morphology features and culture characteristics such as cell density, size and viability [11]. Recently, measurements of cellular downstream volatile organic compound (VOC) emissions were made from the gas exhaust lines in a rocking motion reactor, using Headspace Sorptive Extraction (HSSE) and Stirbar Sorptive Extraction (SBSE) coupled with GC-MS. Unique, total VOC profiles correlated well to cell densities over the course of 8 days. The majority of the relevant VOCs decreased during cell expansion that opens the possibility to monitor the nutrients in the media by VOCs and adjust perfusion rates accordingly [57].

\section{Hollow fiber bioreactors}

A perfusion reactor generally uses a semi-permeable membrane to separate cells from the medium. With this technique, culture medium continuously refreshes nutrients and removes waste metabolites in a system that allows specific flow rates on diverse membrane types, 
Table 4 Further applications of the rocking motion bioreactor

\begin{tabular}{|c|c|c|c|c|c|c|}
\hline $\begin{array}{l}\text { Author - } \\
\text { Year }\end{array}$ & Type & Cell & Disease & Target & Expansion & Functional highlights \\
\hline $\begin{array}{l}\text { Hami }[98] \\
-2004\end{array}$ & $\begin{array}{l}\text { Pre- } \\
\text { clinical }\end{array}$ & $\begin{array}{l}\mathrm{T} \\
\text { cell }\end{array}$ & $\begin{array}{l}\text { Chronic } \\
\text { lymphocytic } \\
\text { leukemia }\end{array}$ & $\begin{array}{l}\text { T cells from Chronic } \\
\text { lymphocytic leukemia patients }\end{array}$ & $\begin{array}{l}400 \text { fold in } \\
13 \text { days }\end{array}$ & $\begin{array}{l}\text { High in vitro activity and T cell receptor repertoire } \\
\text { restored after expansion. }\end{array}$ \\
\hline $\begin{array}{l}\text { Hollyman } \\
{[99]-} \\
2009\end{array}$ & $\begin{array}{l}\text { Pre- } \\
\text { clinical }\end{array}$ & $\begin{array}{l}\top \\
\text { cell }\end{array}$ & $\begin{array}{l}\text { Chronic } \\
\text { lymphocytic } \\
\text { leukemia }\end{array}$ & $\begin{array}{l}\text { T cells from Chronic } \\
\text { lymphocytic leukemia patients }\end{array}$ & $\begin{array}{l}87-668 \text { fold } \\
\text { in } 13-18 \\
\text { days }\end{array}$ & $\begin{array}{l}\text { Transduced and expanded T cells were able to } \\
\text { eradicate the tumors in } 90 \% \text { of a mice population; } \\
\text { release criteria were met }\end{array}$ \\
\hline $\begin{array}{l}\text { Andersen } \\
{[109]-} \\
2016\end{array}$ & Clinical & TIL & $\begin{array}{l}\text { Metastatic } \\
\text { Melanoma }\end{array}$ & $\begin{array}{l}\text { Tumor-Infiltrating Lymphocytes } \\
\text { from Patients with Metastatic } \\
\text { Melanoma }\end{array}$ & $\begin{array}{l}2856-9975 \\
\text { fold in } 13- \\
36 \text { days }\end{array}$ & $\begin{array}{l}\text { Tumor regression was achieved and associated with a } \\
\text { higher absolute number of infused tumor-reactive T } \\
\text { cells }\end{array}$ \\
\hline $\begin{array}{l}\text { Vavrova } \\
{[101]-} \\
2016\end{array}$ & $\begin{array}{l}\text { Pre- } \\
\text { clinical }\end{array}$ & $\begin{array}{l}\top \\
\text { cell }\end{array}$ & $\begin{array}{l}\text { Prostate } \\
\text { Cancer }\end{array}$ & $\begin{array}{l}\text { Prostate cancer reactive T cell } \\
\text { effectors }\end{array}$ & $\begin{array}{l}6 \text { fold in } \\
8 \text { days }\end{array}$ & $\begin{array}{l}\text { Significantly greater cytotoxicity against LNCaP cells } \\
\text { after expansion. }\end{array}$ \\
\hline $\begin{array}{l}\text { Bjoern } \\
{[110]-} \\
2017\end{array}$ & $\begin{array}{l}\text { Pre- } \\
\text { clinical }\end{array}$ & TIL & $\begin{array}{l}\text { Metastatic } \\
\text { Melanoma }\end{array}$ & $\begin{array}{l}\text { Effect of Ipilimumab in } \\
\text { metastatic melanoma derived T } \\
\text { cells }\end{array}$ & - & $\begin{array}{l}\text { Ipilimumab induced marked changes in T cell infiltrates, } \\
\text { which can still be detected despite heavy in vitro } \\
\text { expansion. }\end{array}$ \\
\hline $\begin{array}{l}\text { O'hanlon } \\
\text { [102] - } \\
2017\end{array}$ & Research & $\begin{array}{l}\mathrm{T} \\
\text { cell }\end{array}$ & Non-specific & 19F labeling for T cells & - & $\begin{array}{l}\text { Cellular viability was maintained; } \sim 90 \% \text { of the T cell } \\
\text { preparation was labeled with reagent }\end{array}$ \\
\hline
\end{tabular}

making it suitable for continuous cell culture applications, including monoclonal antibody production [111]. This perfusion principle can be achieved with many different membrane systems. However, the most common solution is the capillary-based hollow fiber membrane. In this system, separation occurs as the medium diffuses between the intra-capillary (IC) and extra-capillary (EC) sides and, depending on the maximum size allowed by the membrane's molecular cut-off, large macromolecules such as cytokines or antibodies are permanently retained on the side where they were originally added [112]. In that way, only small molecules such as carbohydrates, amino acids or small peptides can actually diffuse from and into the compartment where the cells are growing (usually in the EC space), while medium circulates within the IC space [113]. The IC space provides large surface for gas exchange and the cells are not subject to flow therefore they are protected from shear stress [114]. The independent flows in the IC and EC spaces are generated by a set of pumps and valves that direct the fluid through the hollow fiber unit. The basal medium passes through a gas exchange module where sensors are usually placed to monitor parameters such as $\mathrm{pH}$ or DO, and sampling systems are allocated for metabolites' offline analysis. The flow in the EC circuit generally runs countercurrent to the IC flow, ensuring homogenous distribution of nutrients [115].

Perfusion reduces the need for extensive use of culture vessels and multiple incubators [116]; around 80\% decrease in manual labor and incubator space is possible [78]. As the bioreactor uses medium equally or even better than regular static systems [117], up to $30-50 \mathrm{~L}$ of medium that otherwise would be used for static culturing [118] may be economically used for perfusion.
Furthermore, the cells can grow to high concentrations without the metabolites accumulating in the media. Therefore, cells can achieve the required cell-to-cell proximity for optimal expansion in contact demanding cultures such as TILs. Additionally, multiple therapeutic cell doses can be harvested from a single hollow fiber cartridge, enabling periodic use of the bioreactor [78, $118]$. This is also related to the fact that hollow fiber systems are able to support cell growth at densities greater than $10^{8}$ cells $/ \mathrm{mL}$ [113]. While a bag cannot handle optimally more than $2 \times 10^{9}$ cells, a hollow fiber reactor could handle at least twenty times that amount [119]. The possibility of executing cell transfection while the expansion is being performed has also been found advantageous by some authors [120-122] as it combines the process of vector concentration and vector-to-target exposure into a single step.

As previously mentioned, the fluid compartmentalization of hollow fiber bioreactors is advantageous due to the decreased physical stress on the cells. However, excessive recirculation of medium may still lead to negative effects [115]. Protein build-up in the EC space does not directly lead to growth inhibition but its accumulation might also limit the convective flow, creating micro-gradients [123]. Meanwhile, reduced microenvironment homogeneity caused by the axial and radial concentration gradients is challenging, as gravity also influences cell distribution within the bioreactor. Some counteract measures, such as periodical rotation, are usually implemented to prevent the cells from sticking together, disrupting the formation of significant detrimental gradients [123]. Harvesting is also not a straightforward process in some configurations, as the detachment and wash out of the cells from the tight pores might require frequent optimization [24] to retrieve as much cells as possible 
without significantly affecting their integrity and viability; this problem is solved by using a suspension culture configuration, that enables automated sampling and harvesting. In addition, the usually high cell densities attained in the system can be problematic if an electrical or other mechanical issue occurs: the cells do not withstand a decrease in temperature or change in $\mathrm{pH}$ as steadily as they do when grown at moderate densities in bags (around $10^{7}$ cells $/ \mathrm{mL}$ ). It also must be noted that an entire bioreactor has to be harvested to monitor parameters like cytotoxicity, cell phenotype or cell count [72]. A representative sample cannot be periodically obtained from the dense cell culture without performing a major intervention in the system that disrupts the cellular allocation within the fibers while exerts significant shear to remove cells from the thin capillaries, where cell populations are more representative than the cells caught in retention filters. Therefore, culture monitoring is based mainly on physiochemical parameters, or off-line metabolite analysis to the medium effluent, but not on actual cell samples from the culture.

Similar to other expansion systems, it is not easy to compare the performance of different hollow fiber protocols because of differences in the stimulation and culturing strategies (Table 5). The reactor allows the use of cytokines and other growth enhancing additives in high concentration, while significantly reducing the use of serum. Generally, the membranes have a molecular cutoff of 4 to $17 \mathrm{kDa}$ and a very high total surface for optimal diffusion of metabolites. In a typical culture process, cells are seeded at high densities into the EC space, usually after some days of static culture enrichment. But there is at least one exception: the recently introduced Quantum system keeps the cells in the IC space [111, 112], although it allows different seeding configurations depending on the cells to be cultured. The perfusion control strategy is based on the monitoring of the viable cell density by correlating it with non-automated sampling of glucose or lactate concentrations: Glucose consumption and lactate generation rates exhibit logarithmic behavior, correlating with the cells' doubling time $[78,127]$. The culture status may be inferred based on the glucose uptake rates as it reflects the proportion of metabolically active lymphocytes [78]. Although glucose consumption and lactate production rate have been shown to be closely correlated in lymphoid cultures [125], it is possible that lactate levels are not a good indicator of growth inhibiting conditions or nutrient exhaustion, as some cultures seem to grow independently of this metabolite [131].

Initial studies have not found a significant difference in the expansion yield of cells cultured in the hollow fiber bioreactor as compared to the classical static culturing methods [78]. However, later experiments shown conflicting results in this regard (Table 6). Cell expansion is usually in the range of 100 to 200 fold after 1 to 2 weeks of culturing, but newer technologies have reached higher than 500 fold after 8 days [111, 112]. These results should be weighed against the seeding characteristics and the specific stimulation strategy. It also seems that culture performance cannot be easily predicted based on viability or inoculum density [129] as total medium consumption differs between cell donors as a function of the metabolic activity of their cells [78]. Even when the culture performance is highly variable, a lag phase (lasting from 1 to 9 days) is generally observed $[117,119,129]$, then the glucose consumption and lactate production rate change exponentially reaching a plateau or peak after some days of culturing [121, 124]. More pronounced peaks for lactate generation can be seen for high seed cultures, followed by a faster decrease than observed in low seed cultures [112]. The lactate production may start to increase right after inoculation when a static pre-adaptation is performed [120]. Different patterns of cell-produced cytokine concentrations can also be observed during T cell expansions, as TNF $\alpha$, IL-6, IFN $\gamma$ and GM-GSF are proportional to the extent of lymphocyte multiplication, which may depend on cell donor and to the formation of microenvironments, hindering the supply of nutrients and oxygen to some cultures [125].

With respect to product purity, cultures grown in hollow fiber bioreactors have shown to consistently achieve high levels of target cell fraction (Table 7). T cells grown from TILs and PBMCs do not have statistically significant differences in their $\mathrm{CD} 4+/ \mathrm{CD} 8+$ ratios [119, 124], however it has been reported that CD8+ $\mathrm{T}$ cells prefer to expand in low-seed cultures, while $\mathrm{CD} 4+\mathrm{T}$ cells expand more in high-seed cultures [112]. Furthermore, certain shifts in $\mathrm{T}$ cell subpopulations can be higher in bioreactors compared to static cultures [115]. The proportions of CD3+ cells may also increase throughout TIL expansion processes [119]. In general, the stimulation strategy has a greater impact on the cell differentiation profile than the culturing platform, because the stimulation protocol is specifically designed to induce a specific phenotype and may only be enhanced by the direct contact of the cells with the stimulant, which corresponds to the nature of the system. In the same way, bag and hollow fiber cultures have shown similar surface antigen profiles and cytotoxicity [78] with normal cytokine production profile [129] and no functional alteration upon re-stimulation as measured by IFN- $\gamma$, IL-2 and TNF- $\alpha$ secretion [112]. Reactor grown cells also preserve the same biological properties as those grown in static set ups [115] and T-cell products had lower abundance of exhaustion markers [112] when 


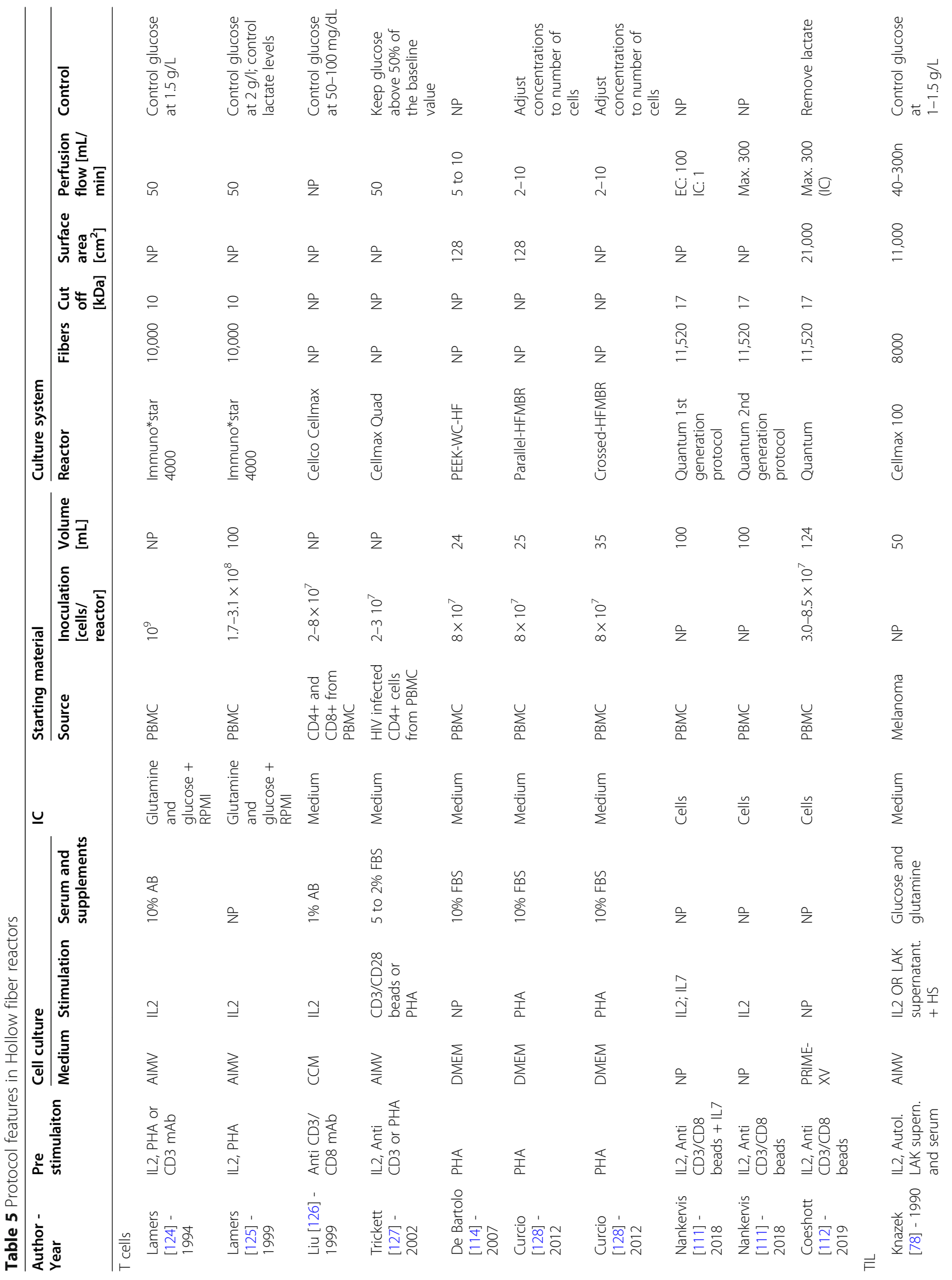




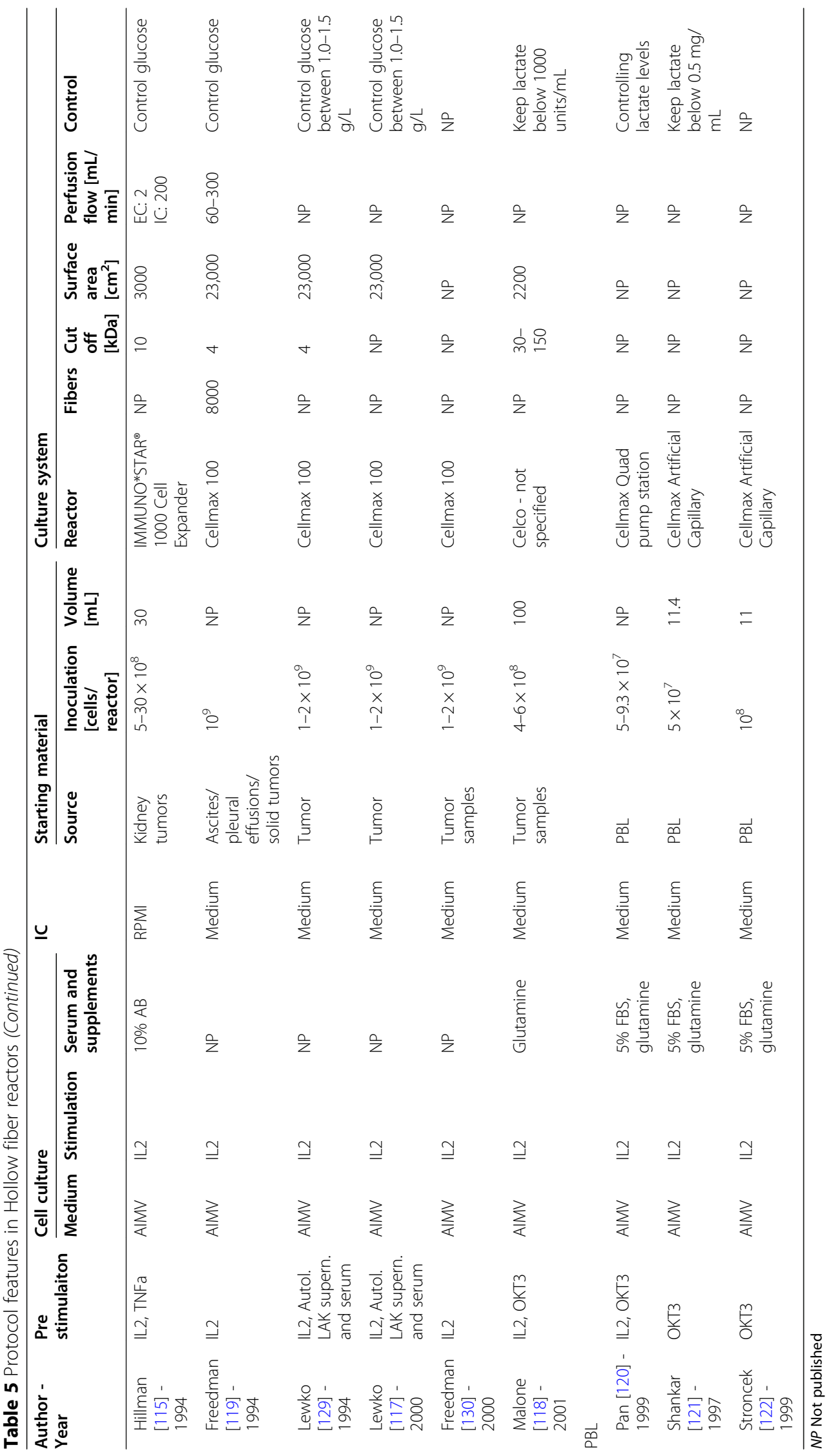


Table 6 Performance differences between static and perfusion reactor cultures

\begin{tabular}{|c|c|c|c|c|c|c|c|}
\hline \multirow{2}{*}{$\begin{array}{l}\text { Author - } \\
\text { Year }\end{array}$} & \multicolumn{5}{|l|}{ Expansion } & \multirow[t]{2}{*}{ Purity } & \multirow[t]{2}{*}{ Functionality changes } \\
\hline & Fold & Days & $\begin{array}{l}\text { Static } \\
\text { control }\end{array}$ & Fold & $\overline{\text { Days }}$ & & \\
\hline \multicolumn{8}{|l|}{$\overline{\mathrm{T} \text { cell }}$} \\
\hline $\begin{array}{l}\text { Lamers } \\
{[124]-} \\
1994\end{array}$ & $52.6 \pm 21.3$ & $14-17$ & Bag & $\begin{array}{l}238.4 \pm \\
168.7\end{array}$ & $\begin{array}{l}14- \\
17\end{array}$ & $\begin{array}{l}C D 4 / C D 8 \text { ratio }=0.51 \pm 0.23 \text { vs. } C D 4 / C D 8= \\
0.44 \pm 0.16 \text { static culture }\end{array}$ & NP \\
\hline $\begin{array}{l}\text { Trickett } \\
{[127]-} \\
2002\end{array}$ & $53.2 \pm 20.1$ & $7-8$ & Flasks & $\begin{array}{l}71.2 \pm \\
42.8\end{array}$ & $7-8$ & NP & NP \\
\hline $\begin{array}{l}\text { Jones [60] } \\
2020\end{array}$ & $\begin{array}{l}17.7 \text { fold } \\
\text { higher } \\
\text { than static }\end{array}$ & 9 & Flask & - & 9 & $\begin{array}{l}\text { Treg phenotype } 93.7 \% \text { for flasks versus } \\
97.7 \% \text { for reactor. }\end{array}$ & $\begin{array}{l}\text { Reactor cultures had 8-fold greater } \\
\text { interleukin-10 stimulation index }\end{array}$ \\
\hline \multicolumn{8}{|l|}{ TIL } \\
\hline $\begin{array}{l}\text { Knazek } \\
{[78]-1990}\end{array}$ & $124-1170$ & $14-32$ & Bag & $\begin{array}{l}\text { No } \\
\text { difference }\end{array}$ & NP & NP & $\begin{array}{l}\text { Bag and hollow fiber cultures has similar } \\
\text { surface-antigen profiles; Cytotoxicity was } \\
\text { similar in both systems }\end{array}$ \\
\hline $\begin{array}{l}\text { Hillman } \\
{[115]-} \\
1994\end{array}$ & $20-60$ & 7 & Plate & 3 & 7 & $\begin{array}{l}\text { Shift in the T cell subpopulations is more } \\
\text { pronounced in the bioreactor. }\end{array}$ & NP \\
\hline $\begin{array}{l}\text { Freedman } \\
{[119]-} \\
1994\end{array}$ & $30.6 \pm 5.6$ & $\begin{array}{l}18.2 \pm \\
1.7\end{array}$ & $\begin{array}{l}\text { Plate, } \\
\text { flask, } \\
\text { bag }\end{array}$ & 303.1 & 28.9 & $\begin{array}{l}\text { CD4/CD8 ratios do not have a statistically } \\
\text { significant difference; no difference in } \\
\text { proportions of } C D 16+\text { and } C D 56\end{array}$ & NP \\
\hline
\end{tabular}

grown in the Quantum System. However, a reduction in cytolytic activity at the end of the culture has also been described [125] and an increase in the concentration of cytokines or growth factors in the medium, produced by the PBLs has been proposed as a reason for overshadowing any inhibitory effects related to the increased lactate levels [122]. There are also alternatives available for perfusion reactors that were not discussed here in details but were used previously for ACT manufacturing (Table 8).

\section{Stirred bioreactors}

While hollow fiber reactors focus on highly efficient and compact cultures, rocking motion systems specialize in easily scalable platforms, the stirred reactor, as the most widespread and classical bioreactor technology, excels in tight process control and straightforward scale up due to easy parametrization, ideal for process intensification. These bioreactors are characterized by a central agitation element, which keeps the medium in motion, thereby maintains cells and stimulants in suspension and provides homogeneous distribution of gases and nutrients [35]. The vessel's geometry, the shape of the impeller and the selected mixing and aeration strategy influence the culture's yield and cell surface markers expression [138]. This translates into a versatile system with high process control capability [89], that provides an efficient mass transfer of oxygen and nutrients, high robustness, precise process control and outstanding scalability. These features enabled stirred reactors to be the first platform employed for lymphoid cells culturing. It was initially used for lymphokine production [73-77], although it was later replaced as more efficient techniques were available for cytokine manufacturing. After that, diffusion of stirred bioreactor into cell therapy was slow and mainly circumscribed to small-scale experimental applications. The spinner flask has been frequently used in that regard, as the simplest stirred vessel, having a couple of side-arm vents for gas and medium exchange and a central stirrer shaft [24]. This reactor is often used as the first step to adapt new cell types to stirring [89]. Culturing cells for ACT in stirred reactors is mainly useful in allogenic therapies, where process scale-up is more important, contrary to scale out primacy with patientspecific applications [11].

As hematopoietic cells are relatively sensitive to shear, the mechanical stress induced by impellers has become a main concern when using a stirred reactor. In that regard, higher than $75 \mathrm{rpm}$ has been found detrimental for some $\mathrm{T}$ cell cultures [139], but such low shear rates may unlikely to produce physical damage to the cells and it is more plausible that the cells actually respond to the transduction of fluid-mechanics forces at a molecular level [63]. Additionally, a decrease in the rate of proliferation has also been observed when gas sparging is used instead of surface aeration, as rupturing bubbles may subject the cells to hydrodynamic forces that could affect the expression of the IL-2R receptor [61]. This receptor has been frequently found to be downregulated in cultures subjected to stirring conditions [139, 140]. In 
Table 7 Performance of non-comparative cultures in hollow fiber reactors

\begin{tabular}{|c|c|c|c|c|c|}
\hline \multirow{2}{*}{$\begin{array}{l}\text { Author - } \\
\text { Year }\end{array}$} & \multicolumn{3}{|l|}{ Expansion } & \multirow[t]{2}{*}{ Purity } & \multirow[t]{2}{*}{ Functionality changes } \\
\hline & Fold & Days & $\begin{array}{l}\text { Media } \\
\text { feed } \\
{[\text { L] }}\end{array}$ & & \\
\hline \multicolumn{6}{|l|}{ T cell } \\
\hline $\begin{array}{l}\text { Lamers } \\
{[125] \text { - }} \\
1999\end{array}$ & $41-149$ & 15 & NR & $\begin{array}{l}\text { Predominantly } \mathrm{CD} 3+\text { and } \\
\mathrm{CD} 8+\end{array}$ & Reduction in cytolytic activity at the end of the culture \\
\hline $\begin{array}{l}\text { Liu [126] - } \\
1999\end{array}$ & $2 \times 10^{5}-10^{8}$ & $\begin{array}{l}50- \\
70\end{array}$ & $N R$ & $\begin{array}{l}95-99 \% \text { CD } 4+\text { CD3 }+ \text { T cells } \\
\text { with virtual elimination of } \\
\text { CD8+ cells }\end{array}$ & $\begin{array}{l}\text { 50-95\% of the cells had elevated expression of HLA-DR.; (IL2R)-a chain } \\
\text { expression was increased; } 40 \text { to } 90 \% \text { of CD25 levels higher than freshly } \\
\text { isolated CD4+ T cells }\end{array}$ \\
\hline \multirow{2}{*}{$\begin{array}{l}\text { Nankervis } \\
{[111]-} \\
2018\end{array}$} & $\begin{array}{l}117,450(1 \mathrm{st} \\
\text { generation) }\end{array}$ & 13 & $2.2-2.4$ & 90.9-98.8\% CD3+ & $N R$ \\
\hline & $\begin{array}{l}439-557 \\
\text { (2nd } \\
\text { generation) }\end{array}$ & 10 & $\begin{array}{l}10.4- \\
13.9\end{array}$ & $98.8-99.5 \%$ CD3+ & NR \\
\hline \multirow[t]{2}{*}{$\begin{array}{l}\text { Coeshott } \\
{[112]-} \\
2019\end{array}$} & $\begin{array}{l}543-1079 \\
\text { (high } \\
\text { seeding) }\end{array}$ & 8 & 19.9 & $\begin{array}{l}91.9-94.5 \% \text { CD3+; } \\
\text { CD4+ expanded preferentially }\end{array}$ & $\begin{array}{l}\text { T-cell products had had low frequencies of cells bearing exhaustion } \\
\text { markers }\end{array}$ \\
\hline & $\begin{array}{l}951-1787 \\
\text { (low } \\
\text { seeding) }\end{array}$ & 9 & 13.6 & $\begin{array}{l}94.2-97.5 \% \text { CD3+; } \\
\text { CD8+ expanded preferentially }\end{array}$ & \\
\hline \multicolumn{6}{|l|}{$\mathrm{TIL}$} \\
\hline $\begin{array}{l}\text { Lewko } \\
{[117,129]} \\
-1994\end{array}$ & 17.3 & 22.3 & 40 & $\begin{array}{l}96 \% \text { T cells based on } \mathrm{CD} 2+ \\
\text { reactivity. }\end{array}$ & Cells produced cytokines normally \\
\hline \multicolumn{6}{|l|}{ PBL } \\
\hline $\begin{array}{l}\text { Pan }[120] \\
-1999\end{array}$ & $104-187$ & $\begin{array}{l}11- \\
12\end{array}$ & NR & NR & $57 \%$ transduction frequency \\
\hline $\begin{array}{l}\text { Shankar } \\
{[121]-} \\
1997\end{array}$ & $\sim 100$ & 10 & 5.5 & NR & $1-10 \%$ transduction frequency \\
\hline $\begin{array}{l}\text { Stroncek } \\
{[122]-} \\
1999\end{array}$ & $\sim 200$ & 17 & NR & NR & $<2.5 \%$ transduction frequency \\
\hline
\end{tabular}

addition to the proved downregulation of IL-2R, agitation could include effects such as changes in gene and protein expression, disturbances in plasma membrane permeability and cell cycle and changes in other intracellular signal pathways [141]. Due to the enhanced interaction between the cells and the stimulant agent, demonstrated increase in cell expansion and phenotype at high stirring levels with cultures that used stimulation beads for cell activation [89]. Although it has been suggested before [61], the use of shear protectant additives has not been investigated yet in stirred reactors. These additives may also prove useful in countering the negative effects observed on the IL-2R downregulation.

Stirred reactors have been applied for expanding $\mathrm{T}$ and NK cells, although cell-to-cell contact-intensive cultures have not been successfully executed yet. Protocols are different (Table 9) but there are several common points. As previously mentioned, almost every protocol use a low stirring range between 50 to $70 \mathrm{rpm}$. The seeding density is usually below $1 \times 10^{6}$ cells $/ \mathrm{mL}$ and the culture is kept at a low cell density throughout the duration of the expansion, implying a very high final culture volume to attain clinically relevant cell counts on the long run. Cell retention by filters has also been applied for stirred vessels [144] but with no remarkable differences from non-perfused cultures. DO levels are set into a 5 to $70 \%$ wide range. Interestingly, hypoxic conditions have frequently been found ideal for cell growth [140, $145,146]$ as the best cell expansion is usually obtained by culturing at the lowest oxygen tension. This phenomenon could be explained by the low mean $\mathrm{O}_{2}$ tension in the hematopoietic and lymphoid organ tissues, that is closer to $40 \mathrm{mmHg}$ (or $5 \% \mathrm{O}_{2}$ in the gas atmosphere), while the anatomical architecture of these organs might expose cells to even lower $\mathrm{O}_{2}$ tensions [145]. In a similar manner, maximum $\mathrm{T}$ cell growth rate has been found to increase at $38.5^{\circ} \mathrm{C}$, although most of the published culturing protocols used $37^{\circ} \mathrm{C}$ [140]. 


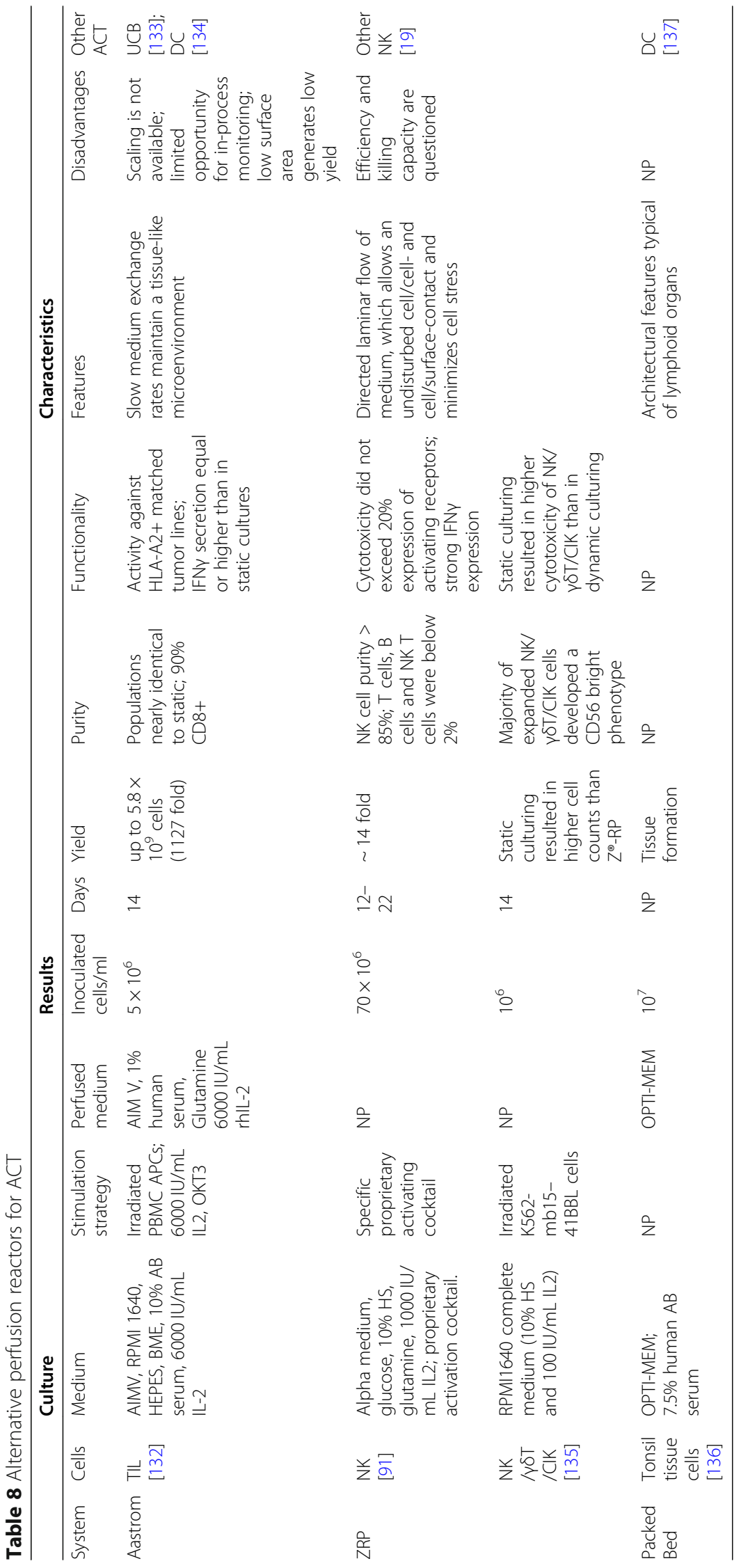




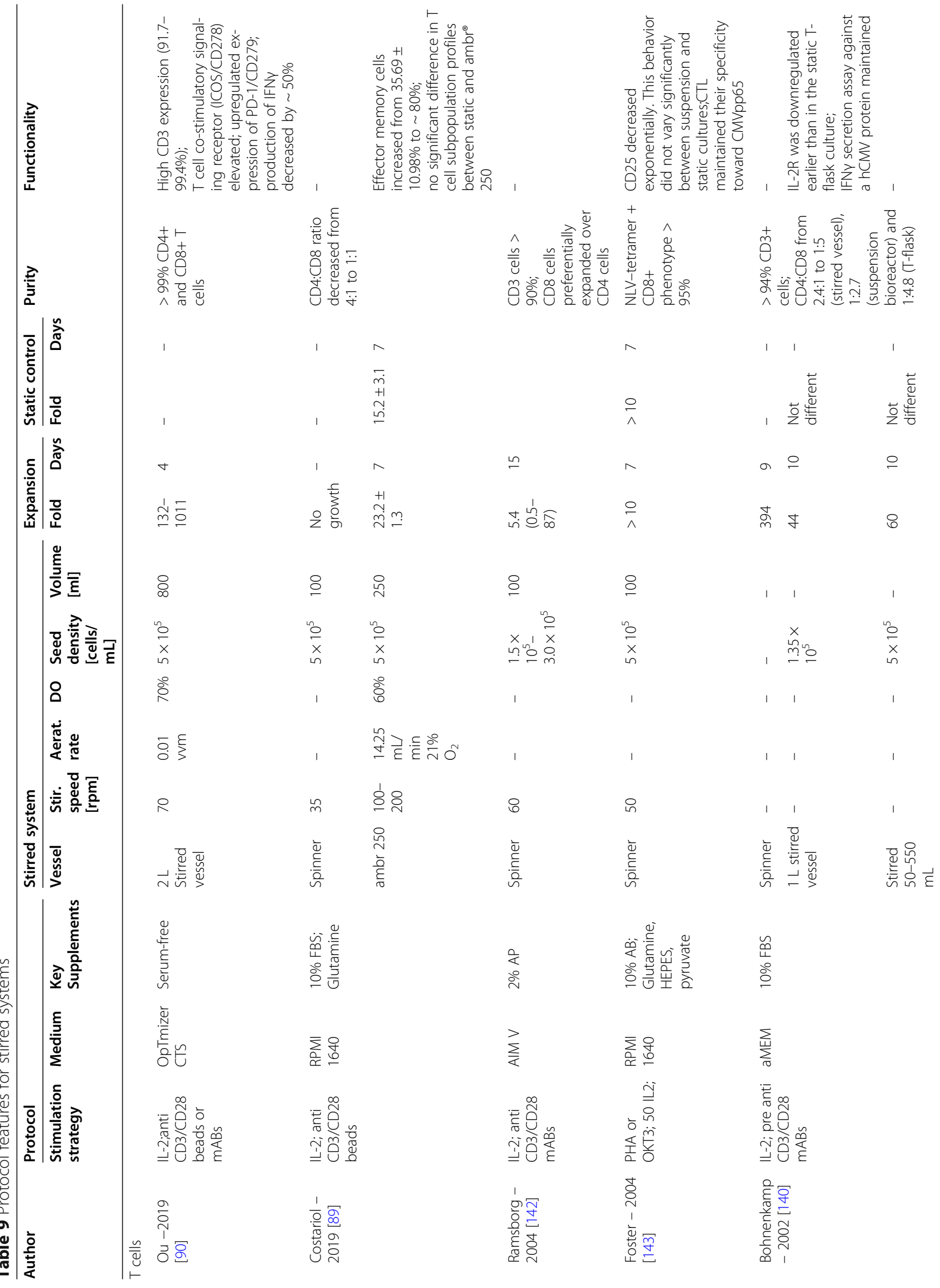




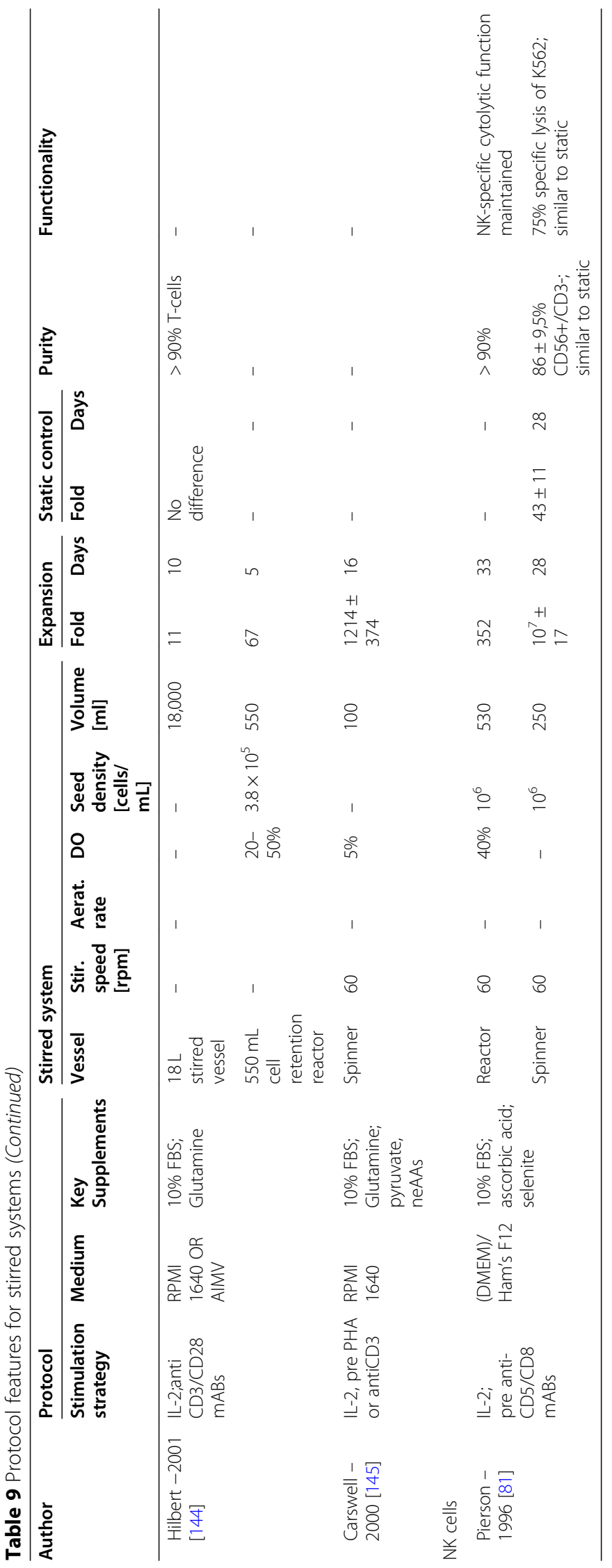


Productivity-wise, and probably because of the operational limitations to avoid any possible damage inflicted by impellers, $T$ cells cultured in stirred reactors experience little $[89,140]$ to insignificant $[61,139,144]$ boosting in their proliferation as compared to static systems. $\mathrm{T}$ cell differentiation have also been found not to be impacted by the agitation regime, with a similar phenotype to static controls [89]. As with other expansion technologies, there is a high expansion variability for cultures processed under the same conditions, likely due to raw material variability. Contrary to $\mathrm{T}$ cells, stirred bioreactors have been found to increase the total NK cell production by 7 fold compared to static cultures [81], however the application of this kind of reactor to NK cells has not been further explored and there is need on additional comparable results to conclude on its potential. Similarly, Peripheral Blood Mononuclear Cells (PBMCs) cultured with $30 \mathrm{rpm}$ stirring speed have shown comparable [147] or superior [148] expansion levels than in static systems. As a comparison with similar cells, cord blood derived hematopoietic stem cells (CB-HSC) have also been found to better expand in stirred systems than in static culture, when agitated between 30 to $40 \mathrm{rpm}[149,150]$. They also present a different expression of genes mainly responsible for chemotactic activity DNA repair and apoptosis [151]. Stirred reactors were also tested for ex-vivo expansion of encapsulated primary human $\mathrm{T}$ lymphocytes, but growth rates were lower in dynamic conditions [152].

The possibility to develop robust control strategies in the ACT field would be one of the main advantages of stirred bioreactors; however, little research has been published in this regard. Pierson et al. [81] tested on-line laser turbidity measurement that reportedly correlated well with cell counts. Recently [46], T-cells cultured in stirred vessels fitted with Raman probes were used to develop chemometric models for glucose $(R=0.987)$, lactate $(R=0.986)$, ammonia $(R=0.936)$, glutamine $(R=$ $0.922)$, and glutamate $(R=0.829)$. Univariate Raman modeling for non-targeted analysis of the culture media was found useful to track the nutrient depletion (glucose and glutamine) and metabolite production (glutamate and lactate), with similar accuracy to the chemometric models. Despite of that, no further research on the application of advanced process analytical technology for stirred cultures in ACT has been done. Manual sampling, coupled with at-line and off-line measurements is routinely performed to measure other process parameters such as cell density, viability, and metabolites concentrations [11]. The lack of process understanding has prevented the development of suitable mechanistic models which still have major discrepancies between predictions and experimental data [153].

\section{Culturing platforms specialized on ACT}

Besides traditional bioreactors, derived from long established bioprocess applications, some expansion technologies were developed to specifically address the requirements of autologous and allogenic ACT. These platforms aim to either provide a physiological-like environment, or to efficiently integrate, from cell acquisition to product formulation, the complex cell therapy workflow into a robust and GMP compliant automated system. Although these platforms have become available just in the last decade, they have been extensively and successfully tested. They are already implemented in clinical practice and cell culture processes, that will be discussed below, are evolved around the devices themselves, hence the different processes are categorized by the culturing platforms they were performed on.

\section{Processes with the G-rex flask}

The G-rex flask is a cylindrical vessel, equipped with a silicon membrane for gas exchange, that enables the usage of a great amount of medium without requiring mechanical assistance for oxygen transfer [106]. Its geometry allows for a set of linearly scalable vessels with a surface area from 5 to $500 \mathrm{~cm}^{2}$ [154], starting from permeable six well plates $[155,156]$, up to $4500 \mathrm{~mL}$ flasks. The increased medium quantity, usually limited by superficial gas diffusion to the cells, supplies nutrients and allows waste dilution into a greater volume, while enhancing close cell-to-cell contact [157], however, the final cell density in a G-rex flask is mainly limited by gas exchange rather than by exhaustion of nutrients [158]. The device includes an automated harvesting unit that allows to perform the expansion in a fully closed system [10]. The G-rex favors differential expansion of specific cell subsets, as it allows oxygen-demanding cells to better survive and proliferate with a more oxidative phenotype and higher levels of mitochondrial activity [159]. Furthermore, it could help to rescue certain lymphocyte lines that can poorly grow in traditional culture devices $[159,160]$. Because of the static culture environment, Grex bioreactors excel in protocols that use APCs such as TILs and antigen-specific T cells [11].

Compared to static systems, the G-rex decreases the amount of manual labor by approximately four times [158] and shortens manufacturing time of some $\mathrm{T}$ cell protocols by half [161]. Even in protocols that couple transfection and expansion, the materials' cost is approximately $38 \%$ less than in a bag-based process [162]. As the G-rex can be used for pre-REP operations, traditional flasks can be entirely eliminated from the manufacturing process [106]. On the other hand, cell expansion kinetics is affected if the cells are disturbed, hindering process sampling [12]. The G-rex flasks cannot incorporate realtime visualization of the cell culture because of their 
standing nature [13]. Unfortunately, even when the G-rex process is scalable, there is still a need for using several flasks to get an adequate number of cells for treatment, increasing cost and workload [33]. However, the versatility of this device has allowed its application to diverse ACT fields: the manufacturing of multi-virus-specific [163166], adenovirus-specific [167], cytomegalovirus-specific [168] and EBV-specific [169] cytotoxic T-cells for infection control after hematopoietic cell transplantation. Furthermore, the GMP manufacturing of NKG2D CAR-T cells for acute myeloid leukemia and multiple myeloma [170], gene-edited NK-92 and YTS cell lines expansion [171] and the generation of TIL for ovarian epithelial cancer [172] were also made possible.

Most of the applications of the G-rex extensively use feeder cells (Table 10), profiting on the enhanced close cell-to-cell interaction. The platform allows expansion levels above 2000 fold for TIL, T cell and NK cell within 2-3 culturing weeks using highly standardized protocols for GMP-grade cell manufacturing. That includes peer-reviewed guides for CTL from PBMC [182, 183] and UCB [184], NK cells [185], TILs [186] and CAR-T cells [157]. When comparing its yield, the expansion of T cells in the G-rex generates up to 100 [173] to 1000 [158] times more cells than classical static culturing techniques, but there are lower yield exceptions [175, 177]. In the same way, NK cells and TILs have also shown better or similar expansion performance, but the difference is moderate $[106,159,180]$. Processes in the G-rex flask also achieve good results regarding cell purity and functionality. The CD4/CD8 ratio of $\mathrm{T}$ cells cultured in the G-rex flask tend to be preserved $[158,160,162]$, while the target cell purity is generally above $90 \%[158,173,174]$. NK cells have also been produced with above $95 \%$ purity, even in complex protocols derived from Umbilical Cord Blood [179]. In TILs, the Phenotype has been found to be similar to static systems [180], with no evidence for cloning selection [159]. Functionality-wise, $\mathrm{T}$ cells grown in the G-rex preserve their cytolytic activity $[158,160,176]$ and some research have found better [177] to similar [162] cytokine expression profile compared to static controls. The cytokine production of TIL grown in G-rex flasks is similar to TIL produced with 24well plates, T-175 flasks, and bags [180].

\section{Processes with the prodigy system}

The Prodigy ${ }^{\circ}$ system integrates cell washing, separation, enrichment and expansion into a fully automated GMP compliant workflow. Prodigy's culturing function is executed by a centrifugation chamber equipped with a microscope camera [92]. The system is able to control temperature, $\mathrm{DO}, \mathrm{pCO}_{2}$ and it can exchange media while performing detailed stimulation protocols using a single set of tubing [92, 187]. The expansion chamber switches from static to dynamic culturing, applying short centrifugation pulses in order to gently mix the cells after stationary intervals that promote cell contact and clustering [188]. Its integrated enrichment and separation functionality has been successfully tested for CD34+ hematopoietic stem cells [131, 189, 190], T cells [191-194] and NK cells [195, 196], decreasing the risk of contamination and increasing process consistency, while reducing personnel and processing time [187], behaving essentially as a "walk away" process for most of the culture period. However, the Prodigy system was designed to be fully closed and automated, rather than to maximize cell expansion. This characteristic is a limit to use the system for protocols requiring large amounts of cells [197]. Thus, if a vast amount of lymphocytes is required for infusion, there will be a need to perform several expansions in multiple devices for a successful therapy [198]. It is expected that new tubing sets with enhanced culturing volume, or the integration of a higher scale bioreactor within the platform [198] could enable a fully automated system that is able to scale from an initial expansion phase to a late cultivation stage at higher culture volumes.

Most of the protocols developed for the Prodigy system couple gene transfer and expansion (Table 11), reaching transduction efficiencies in the range of 20 $30 \%$ [200, 201, 203], 50-60\% [197, 202, 204] and 80\% [199]. Compared to rocking motion cultures, that require a pre-cultivation phase to generate enough cells, a lower cell amount is needed to inoculate an NK [198] or T cell culture [200, 201, 205]. The Prodigy-based lymphoid cultures have shown similar growth kinetics to static systems, such as the G-rex [205], but final yield is usually lower [197, 198]. The maximum increase in cell number is generally below 50 fold after 10-13 days of culturing [187, 188, 197, 199, 202, 204] but there are some higher yield exceptions [200, 203]. Despite of this, over short periods of time, the observed fold expansion is significantly higher than traditional methods, indicating a stable advantage of high yield in brief expansions [202]. NK culturing protocols have consistently reached target cell fractions around 99\% [188, 198] and $\mathrm{T}$ cells have been produced at around $95 \%$ purity [187, 199, 203, 205]. The phenotype profiles of automatically and manually expanded cells have been found to be similar in NK [198] and T cells [197]. Gene expression analysis has shown just slight divergences between NK cells expanded manually or through automation and a similar IFN- $\gamma$ expression in automated and manual NK cultures have been reported [198]. However, IFN- $\gamma$ has also been found to be decreased in Prodigy-based $\mathrm{T}$ cell cultures compared to static protocols [187, 197]. Despite this, the cytotoxicity of products from a Prodigy system have been generally found to be compliant for their clinical application [187, 188, 197, 201-204]. 


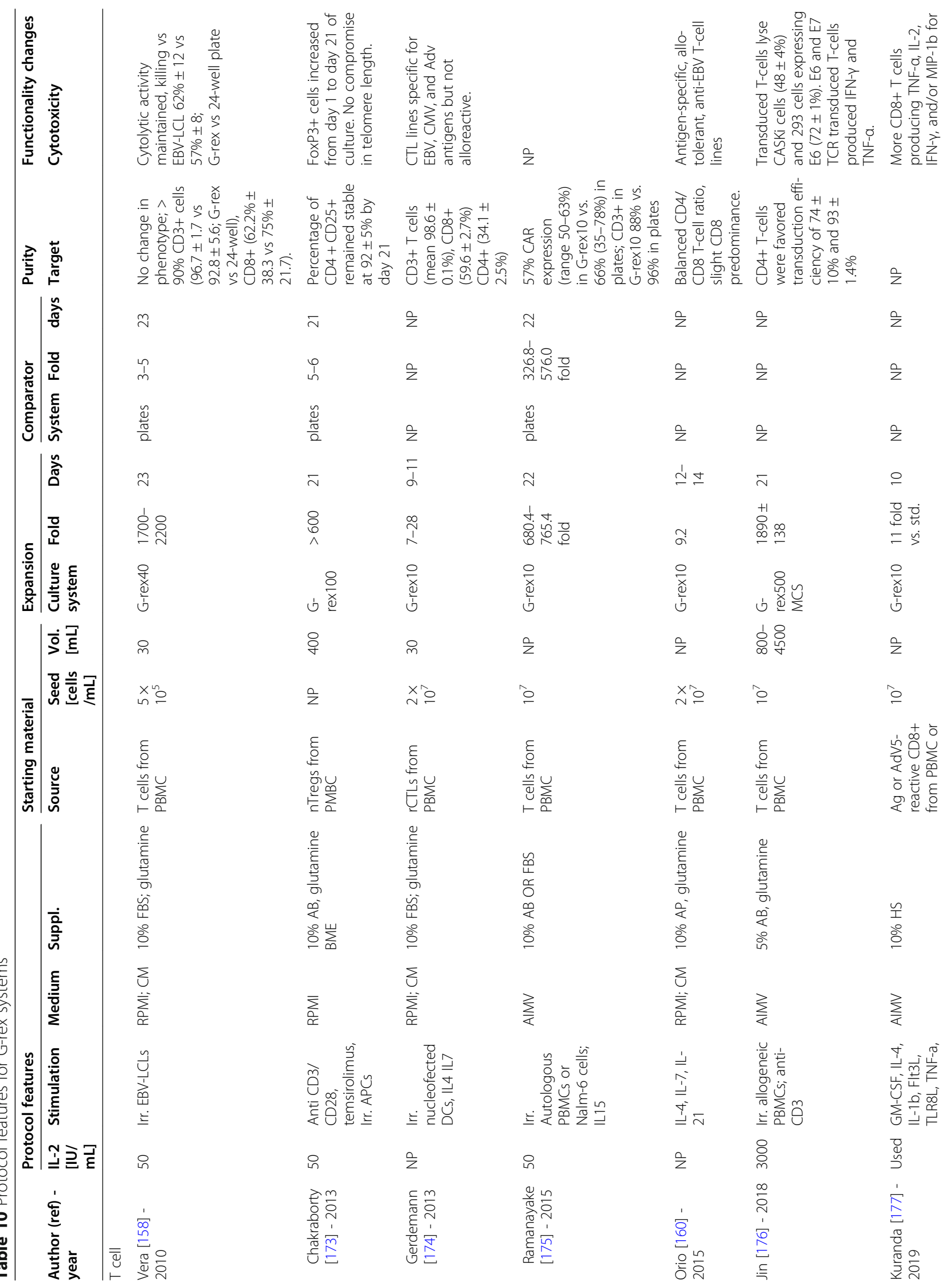




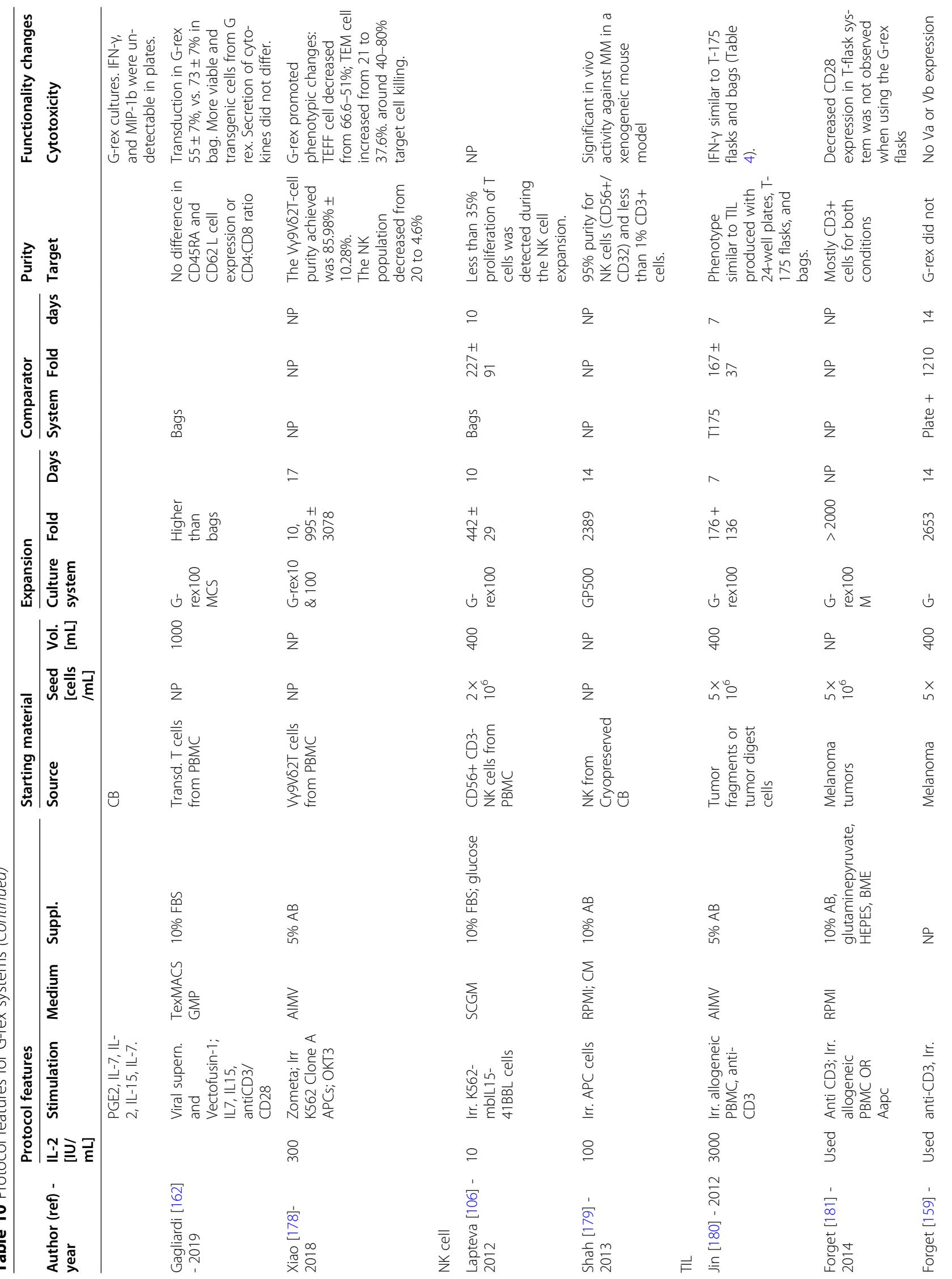




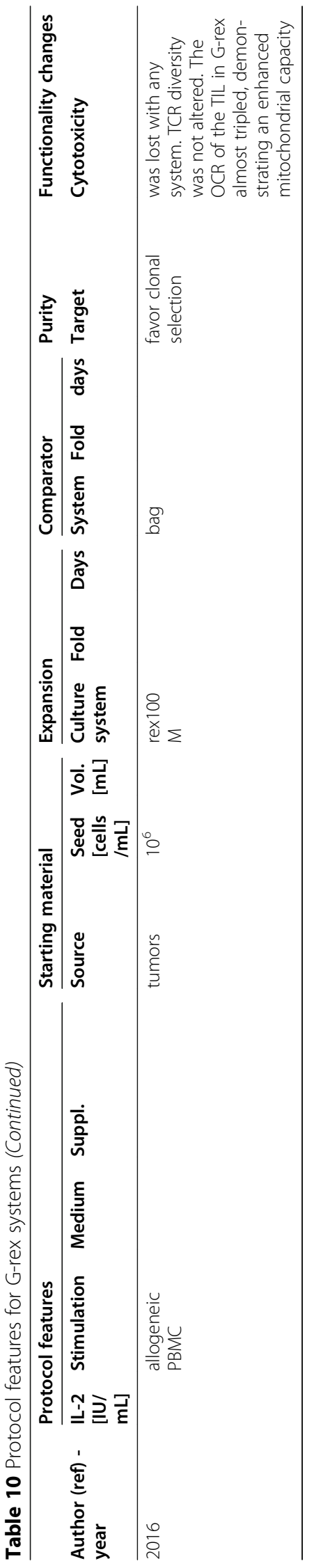




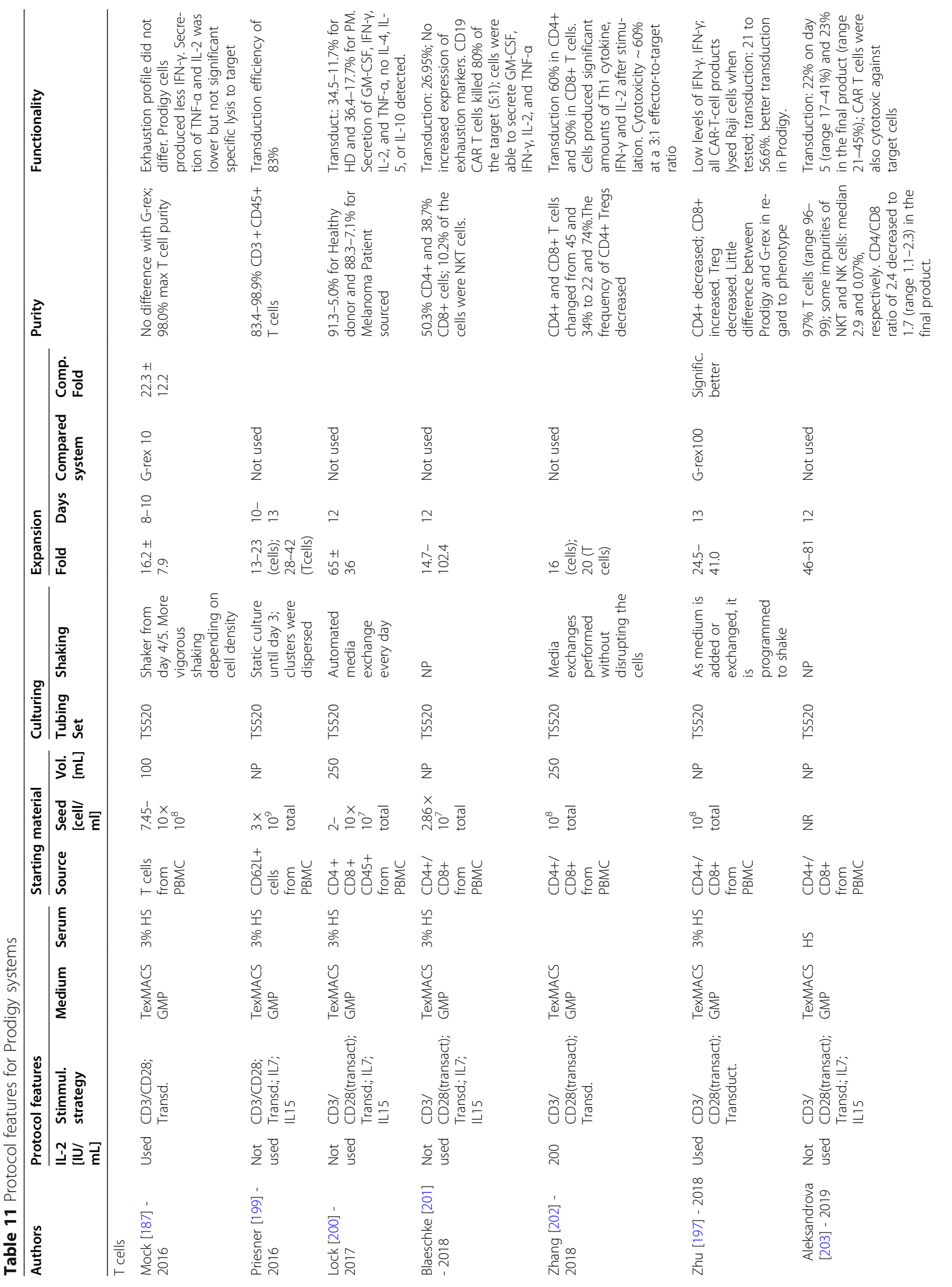




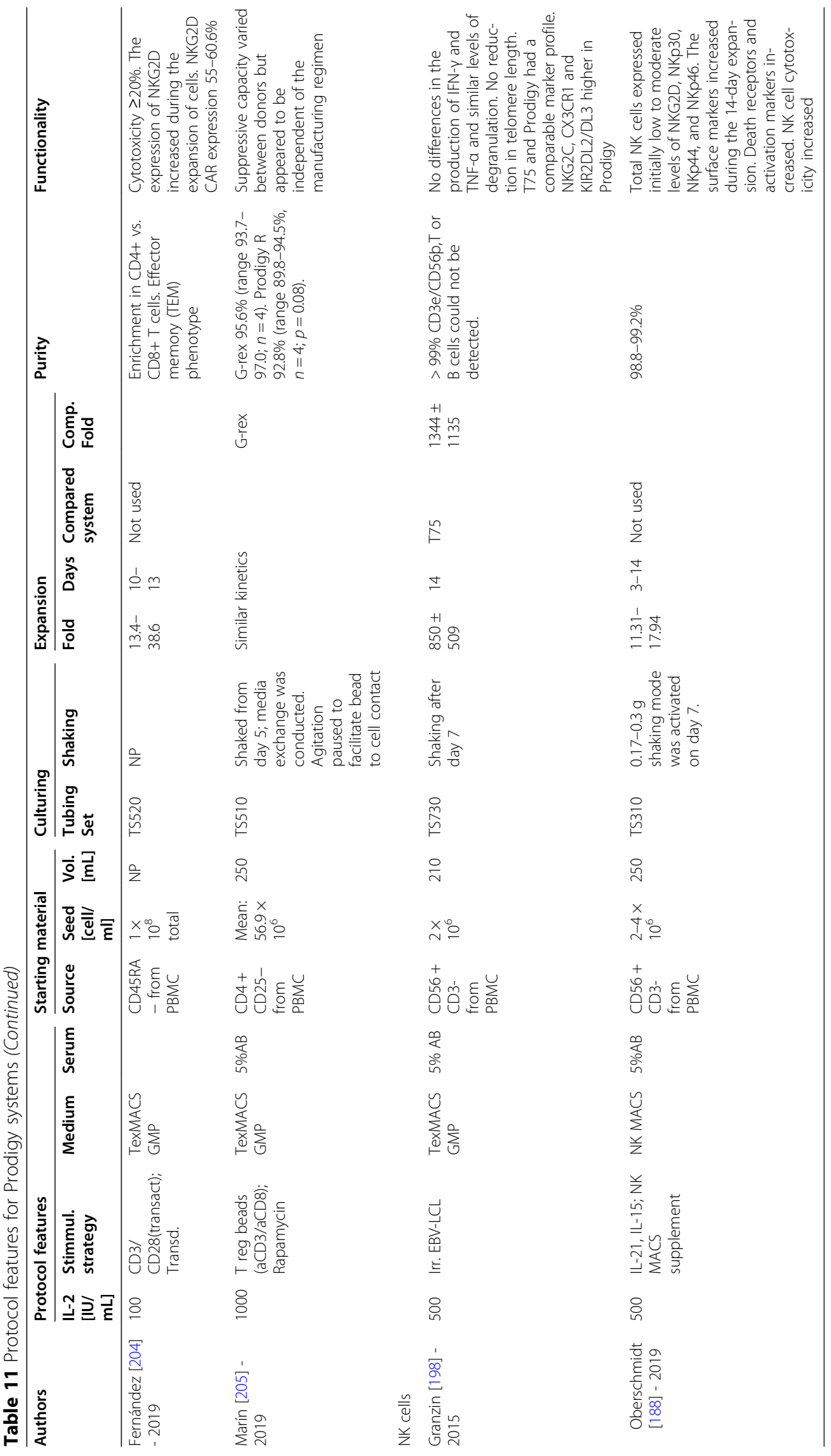




\section{Conclusions}

The goal of this review was to describe and compare different bioreactors that are available for lymphoid cell expansion, summarizing their design features and overall applicability to produce ACT products. Process yield, purity and product functionality were compared to overall expansion results in the context of expansion protocol diversity across different devices. The dependency on a carefully tuned stimulation strategy, high sensitivity to initial conditions and process parameters, translate into high unpredictability of the cultivation process. Reactors are flexible enough to address various ACT challenges, but also limited for some specific lymphocyte culture applications (Fig. 3) Lymphocytes are still frequently expanded totally or partly in conventional, static culture flasks or similar vessels. That is due to the fact that most immune cell types can be grown using this simple and cheap approach without special equipment, but also because those methods fulfill their purpose and, in some instances, have been shown to be even more successful than current bioreactors. The key difference between static and dynamic bioreactor cultures resides in the possibility of process intensification through quality driven approaches and the capacity of harnessing incremental knowledge from ACT manufacturing in a systematic way, compensating for source variability and cell complexity. Furthermore, the bioreactors' ability to precisely control process parameters, mimicking in vivo conditions better than in static cultures, could be beneficial for product quality.

From the user perspective, the main challenges are found in two directions: augment ACT scale and improve process economics. That means increasing predictability of critical process stages such as stimulation schedule, feeding/splitting scheme, in-process testing or point of harvest. During the transition to phase II/III clinical trials and if cellular therapies for high impact cancers (e.g. lung and pancreatic cancer) prove to be successful, a large production scale has to be considered, needing thousands of cell therapeutic doses per year. To get a stable manufacturing pipeline for the large-scale needs, tight process control through continuous monitoring in bioreactors must be already extensively used in routine ACT expansion, which is yet to be achieved. This will be instrumental in

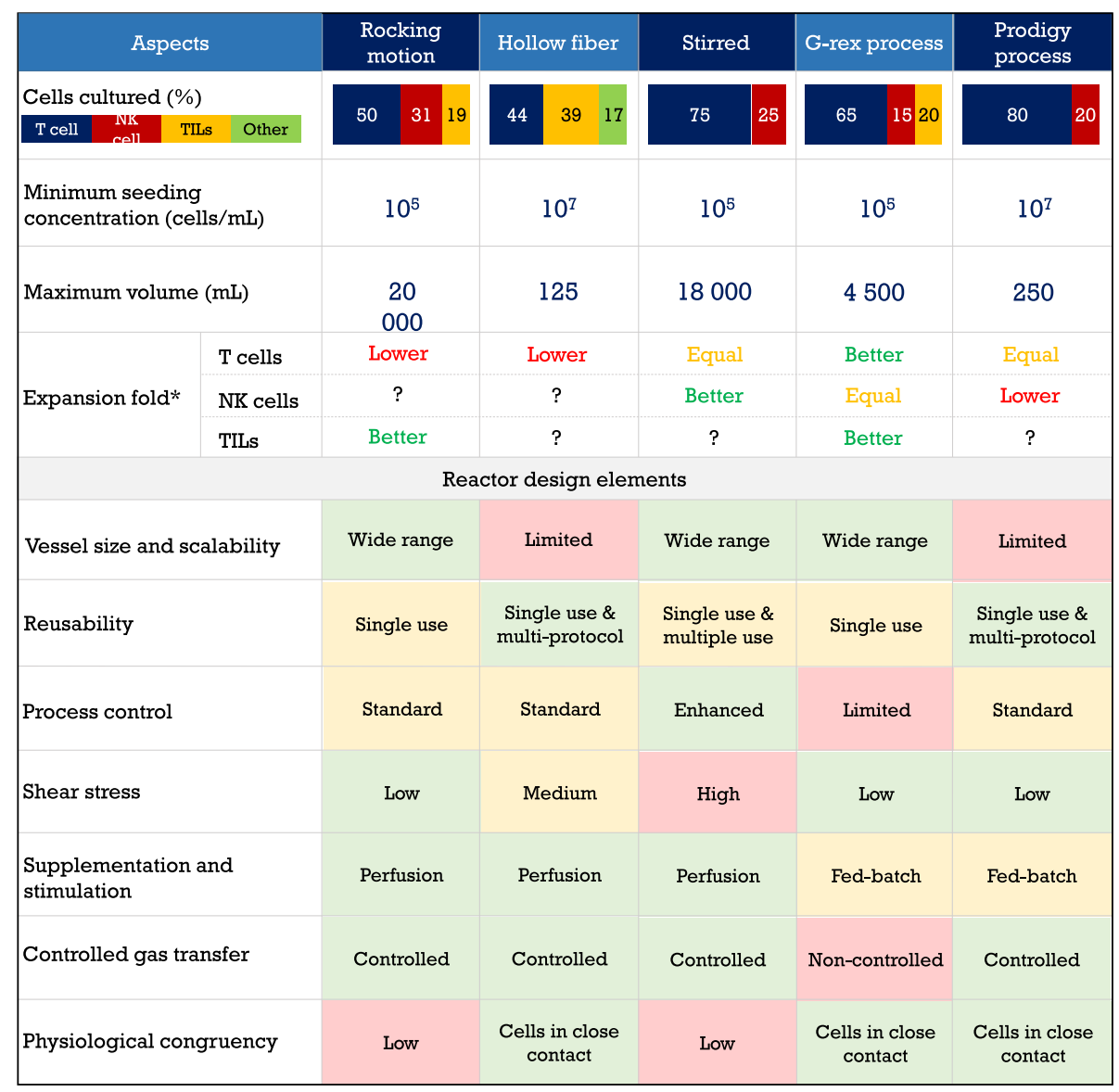

Fig. 3 Summary of the features of the compared bioreactors. * compared to static cultures in bags or flasks 
parameter targeting for optimization, contributing towards process efficiency, increasing the accessibility of therapies to patients.

From the research perspective, the efforts in the development of ACT have been mostly product-oriented, without thoroughly considering the importance of the production process itself [14]. Bioreactors with associated computational modeling and process control will be of great benefit for understanding the mechanisms in which process parameters interact with raw material attributes and the selected stimulation strategy. In that way, cellular metabolic profiles would also provide an additional phenotypic information that can be used to guide cell fate decisions directing the expansion of preferred cell subpopulations in an automated fashion. This aspect of process automation can be used to remove sampling requirements and operator input on run conditions, thereby producing a more consistent, metabolically driven control scheme. The years to come will be framed by the transition towards a process oriented and data intensive ACT paradigm, that should translate current biological understanding into a digitally driven predictive manufacture approach, regardless of the design characteristics of the culturing platform. Every bioreactor layout will still define a specific niche within the immune cell therapeutics, but only those that able to utilize batch-to-batch process knowledge will remain competitive, as ACT is made accessible to a wider range of patients demanding higher flexibility and treatment opportunity.

\footnotetext{
Abbreviations

AB: Pooled human AB Serum; ACT: Adoptive Cell Therapy; AgmDCs: Autologous LNCaP-loaded mature DCs; AP: Autologous Plasma; APCs: Antigen Presenting Cells; ATMPs: Advanced Therapy Medicinal Products; BME: B-mercaptoethanol; CAR: Chimeric Antigen Receptor; CIK: Cytokine-Induced Killer; CMV: Cytomegalovirus; CQAs: Critical Quality Attributes; CTLs: Cytotoxic T Lymphocytes; DC: Dendritic Cells; DMEM: Dulbecco's Modified Eagle's Medium; DO: Dissolved Oxygen; EBV: Epstein-Barr virus; EC: Extra-Capillary; FBS: Fetal Bovine Serum; GCMS: Gas chromatography-mass spectrometry; G-CSF: Granulocyte colonystimulating factor; GLN: Glutamine; GM-CSF: Granulocyte-macrophage Colony-stimulating Factor; GMP: Good Manufacturing Practices; HLADR: Human Leukocyte Antigen - DR isotype complex; HS: Human Serum; HSC: Hematopoietic Stem Cells; HSSE: Headspace Sorptive Extraction; IC: Intra-Capillary; IFN- $\gamma$ : Interferon Gamma; IMDM: Iscove's Modified Dulbecco's Medium; Irr.: Irradiated; LAK: Lymphokine-Activated Killer; LCL: Lymphoblastoid Cell Lines; mAb: Monoclonal Antibody; NCRs: Natural Cytotoxic Receptors; NeAAs: Non-Essential Amino Acids; NK: Natural Killer; NMR: Nuclear Magnetic Resonance; OCR: Oxygen Consumption Rate; PAT: Process Analytical Technology; PBL: Peripheral Blood Lymphocytes; PBMCs: Peripheral Blood Mononuclear Cells; PCA: Principal Component Analysis; PHA: Phytohaemagglutinin; QbD: Quality by Design; REP: Rapid Expansion Protocol; RPMI: Roswell Park Memorial Institute Medium; SBSE: Stirbar Sorptive Extraction; SCGM: Stem Cell Growth Medium; TCR: TCell Receptor; TEFF: Effector T Cells; TILs: Tumor-Infiltrating Lymphocytes; TNFa: Tumor Necrosis Factor Alpha; Treg: Regulatory T-Cell; UCB: Umbilical Cord Blood; VCD: Viable Cell Density; VOC: Volatile Organic Compound
}

\section{Authors' contributions}

OG screened the literature about the usage of bioreactors for cell therapy expansion and prepared the draft of the manuscript. $\mathrm{CH}$ provided supervision and scope related guidance. BK was a major contributor in formulating and structuring the document. All authors read and approved the final manuscript.

\section{Funding}

The authors declare that they have not received any specific funding for the manuscript.

\section{Availability of data and materials}

All data generated or analyzed during this study are included in this published article.

\section{Declarations}

Ethics approval and consent to participate

Not Applicable.

\section{Consent for publication}

Not Applicable.

\section{Competing interests}

The authors declare that they have no competing interests.

Received: 16 December 2020 Accepted: 29 March 2021

Published online: 13 April 2021

\section{References}

1. Hegde PS, Chen DS. Top 10 challenges in Cancer immunotherapy. Immunity. 2020;52(1):17-35.

2. Yang $F$, Jin $H$, Wang J, Sun $Q$, Yan C, Wei F, et al. Adoptive cellular therapy (ACT) for cancer treatment. Adv Exp Med Biol. 2016;909:169-239.

3. Klaver Y, Kunert A, Sleijfer S, Debets R, Lamers CHJ. Adoptive T-cell therapy: a need for standard immune monitoring. Immunotherapy. 2015;7(5):513-33.

4. Rosenberg SA, Restifo NP. Adoptive cell transfer as personalized immunotherapy for human cancer. Science. 2015;348(6230):62-8.

5. Rohaan MW, Wilgenhof S, Haanen JBAG. Adoptive cellular therapies: the current landscape. Virchows Arch Int J Pathol. 2019;474(4):449-61.

6. da Silva JL, Dos Santos ALS, Nunes NCC, de Moraes Lino da Silva F, Ferreira CGM, de Melo AC. Cancer immunotherapy: the art of targeting the tumor immune microenvironment. Cancer Chemother Pharmacol. 2019;84(2):227-40.

7. Dai $X$, Mei $Y$, Nie J, Bai Z. Scaling up the manufacturing process of adoptive T cell immunotherapy. Biotechnol J. 2019;14(4):e1800239.

8. Brenner MK. Adoptive cell therapy: ACT-up or ACT-out? Mol Ther J Am Soc Gene Ther. 2019;27(4):693-4.

9. Abbasalizadeh S, Pakzad M, Cabral JMS, Baharvand H. Allogeneic cell therapy manufacturing: process development technologies and facility design options. Expert Opin Biol Ther. 2017:17(10):1201-19.

10. Highfill SL, Stroncek DF. Overcoming challenges in process development of cellular therapies. Curr Hematol Malig Rep. 2019;14(4):269-77.

11. Iyer RK, Bowles PA, Kim H, Dulgar-Tulloch A. Industrializing autologous adoptive immunotherapies: manufacturing advances and challenges. Front Med (Lausanne). 2018:5:150

12. Wang X, Rivière I. Clinical manufacturing of CAR T cells: foundation of a promising therapy. Mol Ther - Oncolytics. 2016;3:16015.

13. Dwarshuis NJ, Parratt K, Santiago-Miranda A, Roy K. Cells as advanced therapeutics: state-of-the-art, challenges, and opportunities in large scale biomanufacturing of high-quality cells for adoptive immunotherapies. Adv Drug Deliv Rev. 2017;114:222-39.

14. Scibona E, Morbidelli M. Expansion processes for cell-based therapies. Biotechnol Adv. 2019;37(8):107455.

15. Geukes Foppen MH, Donia M, Svane IM, Haanen JB. a. G. tumor-infiltrating lymphocytes for the treatment of metastatic cancer. Mol Oncol. 2015;9(10): 1918-35.

16. Brindley DA, French AL, Baptista R, Timmins N, Adams T, Wall I, et al. Cell therapy bioprocessing technologies and indicators of technological convergence. BioProcess Int. 2014;12(3 SUPPL):14-21.

17. Naing MW, Williams DJ. Three-dimensional culture and bioreactors for cellular therapies. Cytotherapy. 2011;13(4):391-9. 
18. Fischbach MA, Bluestone JA, Lim WA. Cell-based therapeutics: the next pillar of medicine. Sci Transl Med. 2013;5(179):179ps7.

19. Pörtner R, Sebald C, Parida SK, Hoffmeister H. Single-use bioreactors for manufacturing of immune cell therapeutics. In: Single-use Technology in Biopharmaceutical Manufacture: Wiley; 2019. p. 327-34. Available from: https://onlinelibrary.wiley.com/doi/abs/10.1002/9781119477891.ch30. Cited 2019 Nov 26.

20. MacPherson S, Kilgour M, Lum JJ. Understanding lymphocyte metabolism for use in cancer immunotherapy. FEBS J. 2018;285(14):2567-78.

21. Morrow D, Ussi A, Migliaccio G. Addressing pressing needs in the development of advanced therapies. Front Bioeng Biotechnol. 2017;5:55.

22. de Almeida FM, de Matos Branco AD, Fernandes-Platzgummer A, da Silva $\mathrm{CL}$, Cabral JMS. Addressing the manufacturing challenges of cell-based therapies. Adv Biochem Eng Biotechnol. 2020;171:225-78.

23. Vormittag P, Gunn R, Ghorashian S, Veraitch FS. A guide to manufacturing CAR T cell therapies. Curr Opin Biotechnol. 2018;53:164-81.

24. Roh K-H, Nerem RM, Roy K. Biomanufacturing of therapeutic cells: state of the art, current challenges, and future perspectives. Annu Rev Chem Biomol Eng. 2016;7:455-78.

25. Eaker S, Abraham E, Allickson J, Brieva TA, Baksh D, Heathman TRJ, et al. Bioreactors for cell therapies: current status and future advances. Cytotherapy. 2017;19(1):9-18.

26. Kuznetsov SA, Mankani MH, Robey PG. Effect of serum on human bone marrow stromal cells: ex vivo expansion and in vivo bone formation. Transplantation. 2000;70(12):1780-7.

27. Selvaggi TA, Walker RE, Fleisher TA. Development of antibodies to fetal calf serum with arthus-like reactions in human immunodeficiency virus-infected patients given syngeneic lymphocyte infusions. Blood. 1997;89(3):776-9.

28. Stock S, Schmitt M, Sellner L. Optimizing manufacturing protocols of chimeric antigen receptor T cells for improved anticancer immunotherapy. Int J Mol Sci. 2019;20(24):6223.

29. Preethy S, Dedeepiya VD, Senthilkumar R, Rajmohan M, Karthick R, Terunuma $\mathrm{H}$, et al. Natural killer cells as a promising tool to tackle cancer-a review of sources, methodologies, and potentials. Int Rev Immunol. 2017;36(4):220-32.

30. Lee DA. Cellular therapy: adoptive immunotherapy with expanded natural killer cells. Immunol Rev. 2019;290(1):85-99.

31. Poznanski SM, Ashkar AA. What defines NK cell functional fate: phenotype or metabolism? Front Immunol. 2019;10:1414.

32. Piscopo NJ, Mueller KP, Das A, Hematti P, Murphy WL, Palecek SP, et al. Bioengineering solutions for manufacturing challenges in CAR T cells. Biotechnol J. 2018;13(2).

33. Granzin M, Wagner J, Köhl U, Cerwenka A, Huppert V, Ullrich E. Shaping of natural killer cell antitumor activity by ex vivo cultivation. Front Immunol. 2017;8:458.

34. Pörtner R, Parida SK, Schaffer C, Hoffmeister H. Landscape of manufacturing process of ATMP cell therapy products for unmet clinical needs. Stem Cells Clin Pract Tissue Eng. 2017; Available from: https://www.intechopen.com/ books/stem-cells-in-clinical-practice-and-tissue-engineering/landscape-of-ma nufacturing-process-of-atmp-cell-therapy-products-for-unmet-clinical-needs. Cited 2019 Nov 26.

35. Abraham E, Ahmadian BB, Holderness K, Levinson Y, McAfee E. Platforms for manufacturing allogeneic, autologous and iPSC cell therapy products: an industry perspective. Adv Biochem Eng Biotechnol. 2018;165:323-50.

36. Kaiser AD, Assenmacher M, Schröder B, Meyer M, Orentas R, Bethke U, et al. Towards a commercial process for the manufacture of genetically modified T cells for therapy. Cancer Gene Ther. 2015;22(2):72-8.

37. Marshall D, Ward S, Baradez M-O. Requirement for smart in-process control systems to deliver cell therapy processes fit for the 21 st century. Cell Gene Therapy Insights. 2016;2(6):683-9.

38. Lipsitz YY, Timmins NE, Zandstra PW. Quality cell therapy manufacturing by design. Nat Biotechnol. 2016;34(4):393-400.

39. Stephenson M, Grayson W. Recent advances in bioreactors for cell-based therapies. F1000Res. 2018;7:F1000 Faculty Rev-517.

40. Levinson Y, Beri RG, Holderness K, Ben-Nun IF, Shi Y, Abraham E. Bespoke cell therapy manufacturing platforms. Biochem Eng J. 2018;132:262-9.

41. Pigeau GM, Csaszar E, Dulgar-Tulloch A. Commercial scale manufacturing of allogeneic cell therapy. Front Med (Lausanne). 2018;5:233.

42. Moutsatsou P, Ochs J, Schmitt RH, Hewitt CJ, Hanga MP. Automation in cell and gene therapy manufacturing: from past to future. Biotechnol Lett. 2019; 41(11):1245-53.
43. Kirouac DC, Zandstra PW. The systematic production of cells for cell therapies. Cell Stem Cell. 2008;3(4):369-81.

44. Pollard D, Kistler C. Disposable bioreactors. In: Current developments in biotechnology and bioengineering: bioprocesses, bioreactors and controls; 2017. p. 353-79.

45. Cierpka K, Elseberg CL, Niss K, Kassem M, Salzig D, Czermak P. hMSC production in disposable bioreactors with regards to GMP and PAT. Chem Ing Tech. 2013:85(1-2):67-75.

46. Baradez M-O, Biziato D, Hassan E, Marshall D. Application of Raman spectroscopy and Univariate Modelling as a process analytical Technology for Cell Therapy Bioprocessing. Front Med. 2018;5:47.

47. Chen M, McReynolds N, Campbell EC, Mazilu M, Barbosa J, Dholakia K, et al. The use of wavelength modulated Raman spectroscopy in label-free identification of T lymphocyte subsets, natural killer cells and dendritic cells. PLoS One. 2015;10(5):e0125158.

48. Hobro AJ, Kumagai Y, Akira S, Smith NI. Raman spectroscopy as a tool for label-free lymphocyte cell line discrimination. Analyst. 2016;141(12):3756-64.

49. Alhusban AA, Breadmore MC, Gueven N, Guijt RM. Capillary electrophoresis for automated on-line monitoring of suspension cultures: correlating cell density, nutrients and metabolites in near real-time. Anal Chim Acta. 2016; 920:94-101.

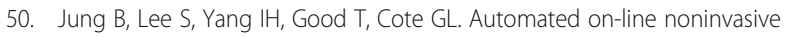
optical glucose monitoring in a cell culture system. Appl Spectrosc. 2002; 56(1):51-7.

51. Cerignoli F, Abassi YA, Lamarche BJ, Guenther G, Ana DS, Guimet D, et al. In vitro immunotherapy potency assays using real-time cell analysis. PLoS One. 2018;13(3):e0193498

52. Oberg H-H, Peters C, Kabelitz D, Wesch D. Real-time cell analysis (RTCA) to measure killer cell activity against adherent tumor cells in vitro. Methods Enzymol. 2020;631:429-41.

53. Peper JK, Schuster H, Löffler MW, Schmid-Horch B, Rammensee H-G, Stevanović S. An impedance-based cytotoxicity assay for real-time and label-free assessment of T-cell-mediated killing of adherent cells. J Immunol Methods. 2014:405:192-8.

54. Crowe SM, Kintzios S, Kaltsas G, Palmer CS. A bioelectronic system to measure the glycolytic metabolism of activated CD4+ T cells. Biosensors. 2019;9(1):10.

55. Singh M, Truong J, Reeves WB, Hahm J-I. Emerging cytokine biosensors with optical detection modalities and nanomaterial-enabled signal enhancement. Sensors. 2017;17(2):428.

56. Revzin A, Maverakis E, Chang H-C. Biosensors for immune cell analysis-a perspective. Biomicrofluidics. 2012;6(2):021301.

57. McCartney MM, Yamaguchi MS, Bowles PA, Gratch YS, lyer RK, Linderholm $\mathrm{AL}$, et al. Volatile organic compound (VOC) emissions of $\mathrm{CHO}$ and T cells correlate to their expansion in bioreactors. J Breath Res. 2019;14(1):016002.

58. Martin I, Simmons PJ, Williams DF. Manufacturing challenges in regenerative medicine. Sci Transl Med. 2014;6(232):232fs 16.

59. Henstock JR, El Haj AJ. Bioreactors. In: Mechanobiology: Exploitation for Medical Benefit; 2016. p. 275-96.

60. Jones M, Nankervis B, Santos-Roballo K, Pham H, Bushman J, Coeshott C. A comparison of automated perfusion- and manual diffusion-based human regulatory $T$ cell expansion and functionality using a soluble activator complex. Cell Transplant. 2020;29:1-15.

61. Carswell KS, Papoutsakis ET. Culture of human T cells in stirred bioreactors for cellular immunotherapy applications: shear, proliferation, and the IL-2 receptor. Biotechnol Bioeng. 2000;68(3):328-38.

62. Larbi A, Cabreiro F, Zelba H, Marthandan S, Combet E, Friguet B, et al. Reduced oxygen tension results in reduced human $T$ cell proliferation and increased intracellular oxidative damage and susceptibility to apoptosis upon activation. Free Radic Biol Med. 2010;48(1):26-34.

63. Nielsen LK. Bioreactors for hematopoietic cell culture. Annu Rev Biomed Eng. 1999;1:129-52.

64. Somerville RPT, Devillier L, Parkhurst MR, Rosenberg SA, Dudley ME. Clinical scale rapid expansion of lymphocytes for adoptive cell transfer therapy in the WAVE ${ }^{\circledR}$ bioreactor. J Transl Med. 2012;10:69.

65. Lapteva N, Szmania SM, van Rhee F, Rooney CM. Clinical grade purification and expansion of natural killer cells. Crit Rev Oncog. 2014;19(1-2):121-32.

66. Tran C-A, Burton L, Russom D, Wagner JR, Jensen MC, Forman SJ, et al. Manufacturing of large numbers of patient-specific T cells for adoptive immunotherapy: an approach to improving product safety, composition, and production capacity. J Immunother. 2007;30(6):644-54. 
67. Chrobok M, Dahlberg CIM, Sayitoglu EC, Beljanski V, Nahi H, Gilljam M, et al. Functional assessment for clinical use of serum-free adapted NK-92 cells. Cancers. 2019;11(1):69.

68. Rosenberg SA. Adoptive immunotherapy of cancer using lymphokine activated killer cells and recombinant interleukin-2. Important Adv Oncol. 1986:55-91.

69. Rosenberg SA, Spiess P, Lafreniere R. A new approach to the adoptive immunotherapy of cancer with tumor-infiltrating lymphocytes. Science. 1986;233(4770):1318-21.

70. Rosenberg SA, Packard BS, Aebersold PM, Solomon D, Topalian SL, Toy ST, et al. Use of tumor-infiltrating lymphocytes and interleukin-2 in the immunotherapy of patients with metastatic melanoma. A preliminary report. N Engl J Med. 1988;319(25):1676-80.

71. Rosenberg SA, Lotze MT, Muul LM, Chang AE, Avis FP, Leitman S, et al. A progress report on the treatment of 157 patients with advanced cancer using lymphokine-activated killer cells and interleukin-2 or high-dose interleukin-2 alone. N Engl J Med. 1987:316(15):889-97.

72. Yannelli JR. The preparation of effector cells for use in the adoptive cellular immunotherapy of human cancer. J Immunol Methods. 1991;139(1):1-16.

73. Bödeker BG, Lehmann J, Mühlradt PF. Lymphokine (interleukin-2) production by mitogen-stimulated human lymphocytes in small reactors. Dev Biol Stand. 1981;50:193-200.

74. Bödekeri BGD, Lehmann J, Van Damme J, Kappmeyer H, Gassel W-D, Havemann $\mathrm{K}$, et al. Production of five human Lymphokines (GranulocyteMacrophage Colony stimulating factor, interferon- $\gamma$, interleukin 2, macrophage cytotoxicity factor and macrophage migration inhibitory factor) from con a stimulated lymphocyte cultures in bioreactors. Immunobiology. 1984;166(1):12-23.

75. Pauly JL, Russell CW, Planinsek JA, Minowada J. Studies of cultured human T lymphocytes. I. Production of the T cell growth-promoting lymphokine interleukin-2. J Immunol Methods. 1982;50(2):173-86.

76. Braude IA. A simple and efficient method for the production of human gamma interferon. J Immunol Methods. 1983;63(2):237-46.

77. Grote W, Klaar J, Mühlradt PF, Monner DA. Large scale production and purification of human IL-2 from buffy coat lymphocytes stimulated with 12O-tetradecanoylphorbol 13-acetate and calcium ionohore A23187. J Immunol Methods. 1987;103(1):15-25.

78. Knazek RA, Wu Y-W, Aebersold PM, Rosenberg SA. Culture of human tumor infiltrating lymphocytes in hollow fiber bioreactors. J Immunol Methods. 1990;127(1):29-37.

79. Alter BJ, Ochoa AC, Gruenberg ML, Keyport GM, Bach FH. The growth of cells with LAK activity in an automated tissue culture system (Acusyst P). Prog Clin Biol Res. 1987;244:301-11.

80. Tanji Y, Tanaka T, Kimoto Y, Fujiwara A, Fujita M, Taguchi T. Mass culture of LAK cells by hollow-fiber bioreactor system. Jpn I Cancer Chemother. 1989; 16(4 II-3):1888-92.

81. Pierson BA, Europa AF, Hu W-S, Miller JS. Production of human natural killer cells for adoptive immunotherapy using a computer-controlled stirred-tank bioreactor. J Hematother. 1996:5(5):475-83.

82. Murata $M$, Yano $T$, Togami $M$, Yasumoto $K$, Sugimachi $K$, Kimura $G$, et al. Development of a new culture system for human lymphokine-activated killer cells. J Immunol Methods. 1990;129(1):89-95.

83. Walther I, Pippia P, Meloni MA, Turrini F, Mannu F, Cogoli A. Simulated microgravity inhibits the genetic expression of interleukin-2 and its receptor in mitogen-activated T lymphocytes. FEBS Lett. 1998;436(1):115-8.

84. Bakos A, Varkonyi A, Minarovits J, Batkai L. Effect of simulated microgravity on human lymphocytes. J Gravit Physiol J Int Soc Gravit Physiol. 2001:8(1):69-70

85. Risin D, Pellis NR. Modeled microgravity inhibits apoptosis in peripheral blood lymphocytes. In Vitro Cell Dev Biol Anim. 2001;37(2):66-72.

86. Ward NE, Pellis NR, Risin SA, Risin D. Gene expression alterations in activated human T-cells induced by modeled microgravity. J Cell Biochem. 2006;99(4): 1187-202.

87. Li Q, Mei Q, Huyan T, Xie L, Che S, Yang H, et al. Effects of simulated microgravity on primary human NK cells. Astrobiology. 2013;13(8):703-14.

88. Bradley JH, Stein R, Randolph B, Molina E, Arnold JP, Gregg RK. T cell resistance to activation by dendritic cells requires long-term culture in simulated microgravity. Life Sci Space Res. 2017;15:55-61.

89. Costariol E, Rotondi M, Amini A, Hewitt CJ, Nienow AW, Heathman TRJ, et al. Establishing the scalable manufacture of primary human T-cells in an automated stirred-tank bioreactor. Biotechnol Bioeng. 2019;116(10):2488-502.
90. Ou J, Si Y, Tang Y, Salzer GE, Lu Y, Kim S, et al. Novel biomanufacturing platform for large-scale and high-quality human T cells production. J Biol Eng. 2019;13(1):34

91. Bröker K, Sinelnikov E, Gustavus D, Schumacher U, Pörtner R, Hoffmeister H, et al. Mass production of highly active nk cells for cancer immunotherapy in a gmp conform perfusion bioreactor. Front Bioeng Biotechnol. 2019;7:194

92. Apel M, Brüning M, Granzin M, Essl M, Stuth J, Blaschke J, et al. Integrated clinical scale manufacturing system for cellular products derived by magnetic cell separation, centrifugation and cell culture. Chem Ing Tech. 2013;85(1-2):103-10.

93. Singh V. Disposable bioreactor for cell culture using wave-induced agitation Cytotechnology. 1999;30(1-3):149-58.

94. Sutlu T, Stellan B, Gilljam M, Quezada HC, Nahi H, Gahrton G, et al. Clinicalgrade, large-scale, feeder-free expansion of highly active human natural killer cells for adoptive immunotherapy using an automated bioreactor. Cytotherapy. 2010;12(8):1044-55.

95. Eibl R, Eibl D. Application of disposable bag bioreactors in tissue engineering and for the production of therapeutic agents. Adv Biochem Eng Biotechnol. 2009;112:183-207.

96. EIBL R, EIBL D. Design and use of the wave bioreactor for plant cell culture. In: Gupta SD, Ibaraki Y, editors. Plan tissue culture engineering. Dordrecht: Springer Netherlands; 2006. p. 203-27. (Focus on Biotechnology). Available from: https://doi.org/10.1007/978-1-4020-3694-1_12. Cited 2019 Nov 10.

97. Meng Y, Sun J, Hu T, Ma Y, Du T, Kong C, et al. Rapid expansion in the WAVE bioreactor of clinical scale cells for tumor immunotherapy. Hum Vaccines Immunother. 2018;14(10):2516-26.

98. Hami LS, Green C, Leshinsky N, Markham E, Miller K, Craig S. GMP production and testing of Xcellerated T cells $s^{T M}$ for the treatment of patients with CLL. Cytotherapy. 2004;6(6):554-62.

99. Hollyman D, Stefanski J, Przybylowski M, Bartido S, Borquez-Ojeda O, Taylor $C$, et al. Manufacturing validation of biologically functional T cells targeted to CD19 antigen for autologous adoptive cell therapy. J Immunother. 2009; 32(2):169-80.

100. Janas M, Nunes C, Marenghi A, Sauvage V, Davis B, Bajaj A, et al. Perfusion's role in maintenance of high-density T-cell cultures. BioProcess Int. 2015; 13(1):18-26.

101. Vavrova K, Vrabcova P, Filipp D, Bartunkova J, Horvath R. Generation of T cell effectors using tumor cell-loaded dendritic cells for adoptive $T$ cell therapy. Med Oncol. 2016;33(12):136.

102. O'Hanlon CF, Fedczyna T, Eaker S, Shingleton WD, Helfer BM. Integrating a $19 \mathrm{~F} \mathrm{MRI}$ tracer agent into the clinical scale manufacturing of a T-cell immunotherapy. Contrast Media Mol Imaging. 2017;2017:9548478.

103. Smith TA. CAR-T cell expansion in a Xuri cell expansion system W25. Methods Mol Biol Clifton NJ. 2020;2086:151-63.

104. Spanholtz J, Preijers F, Tordoir M, Trilsbeek C, Paardekooper J, de Witte T, et al. Clinical-grade generation of active NK cells from cord blood hematopoietic progenitor cells for immunotherapy using a closed-system culture process. PLoS One. 2011;6(6):e20740 Kaufman D, editor.

105. Rujkijyanont P, Chan WK, Eldridge PW, Lockey T, Holladay M, Rooney B, et al. Ex vivo activation of CD56+ immune cells that eradicate neuroblastoma. Cancer Res. 2013;73(8):2608-18.

106. Lapteva N, Durett AG, Sun J, Rollins LA, Huye LL, Fang J, et al. Large-scale ex vivo expansion and characterization of natural killer cells for clinical applications. Cytotherapy. 2012;14(9):1131-43.

107. Sadeghi A, Pauler L, Annerén C, Friberg A, Brandhorst D, Korsgren O, et al. Large-scale bioreactor expansion of tumor-infiltrating lymphocytes. J Immunol Methods. 2011;364(1-2):94-100.

108. Donia M, Larsen SM, Met T, Svane IM. Simplified protocol for clinical-grade tumor-infiltrating lymphocyte manufacturing with use of the wave bioreactor. Cytotherapy. 2014;16(8):1117-20.

109. Andersen R, Donia M, Ellebaek E, Borch TH, Kongsted P, Iversen TZ, et al. Long-lasting complete responses in patients with metastatic melanoma after adoptive cell therapy with tumor-infiltrating lymphocytes and an attenuated il2 regimen. Clin Cancer Res. 2016;22(15):3734-45.

110. Bjoern J, Lyngaa R, Andersen R, Rosenkrantz LH, Hadrup SR, Donia M, et al. Influence of ipilimumab on expanded tumour derived $T$ cells from patients with metastatic melanoma. Oncotarget. 2017;8(16):27062-74.

111. Nankervis B, Jones M, Vang B, Brent Rice R Jr, Coeshott C, Beltzer J. Optimizing T cell expansion in a hollow-Fiber bioreactor. Curr Stem Cell Rep. 2018;4(1):46-51. 
112. Coeshott C, Vang B, Jones M, Nankervis B. Large-scale expansion and characterization of CD3+ T-cells in the quantum ${ }^{\circledR}$ cell expansion system. J Transl Med. 2019;17(1):258.

113. Cadwell JJS. New developments in hollow-fiber cell culture. Am Biotechnol Lab. 2004;22(8):14.

114. De Bartolo L, Piscioneri A, Cotroneo G, Salerno S, Tasselli F, Campana C, et al. Human lymphocyte PEEK-WC hollow fiber membrane bioreactor. J Biotechnol. 2007;132(1):65-74.

115. Hillman GG, Wolf ML, Montecillo E, Younes E, Ali E, Pontes JE, et al. Expansion of activated lymphocytes obtained from renal cell carcinoma in an automated hollow fiber bioreactor. Cell Transplant. 1994;3(4):263-71.

116. Yannelli JR, Hyatt C, McConnell S, Hines K, Jacknin L, Parker L, et al. Growth of tumor-infiltrating lymphocytes from human solid cancers: summary of a 5-year experience. Int J Cancer. 1996;65(4):413-21.

117. Lewko WM, Hall PB, Oldham RK. Growth of tumor-derived activated T cells for the treatment of advanced cancer. Cancer Biother Radiopharm. 2000; 15(4):357-66.

118. Malone CC, Schiltz PM, Mackintosh AD, Beutel LD, Heinemann FS, Dillman $\mathrm{RO}$. Characterization of human tumor-infiltrating lymphocytes expanded in hollow-fiber bioreactors for immunotherapy of cancer. Cancer Biother Radiopharm. 2001;16(5):381-90.

119. Freedman RS, Tomasovic B, Templin S, Atkinson EN, Kudelka A, Edwards CL, et al. Large-scale expansion in interleukin-2 of tumor-infiltrating lymphocytes from patients with ovarian carcinoma for adoptive immunotherapy. J Immunol Methods. 1994;167(1-2):145-60.

120. Pan D, Shankar R, Stroncek DF, Whitley CB. Combined ultrafiltrationtransduction in a hollow-fiber bioreactor facilitates retrovirus-mediated gene transfer into peripheral blood lymphocytes from patients with mucopolysaccharidosis type II. Hum Gene Ther. 1999;10(17):2799-810.

121. Shankar R, Whitley CB, Pan D, Burger S, McCullough J, Stroncek D. Retroviral transduction of peripheral blood leukocytes in a hollow- fiber bioreactor. Transfusion (Paris). 1997:37(7):685-90.

122. Stroncek DF, Hubel A, Shankar RA, Burger SR, Pan D, McCullough J, et al. Retroviral transduction and expansion of peripheral blood lymphocytes for the treatment of mucopolysaccharidosis type II, Hunter's syndrome. Transfusion (Paris). 1999:39(4):343-50.

123. Wolf ML, Hirschel MD. Growing TIL and LAK cells in hollow fibre bioreactors. In: Animal Cell Biotechnology; 1994. p. 237-58.

124. Lamers CHJ, van de Griend RJ, Gratama JW, RLH B. Activation and expansion of Hunan cytotoxic T lymphocytes in hollow fiber bioreactors. In: Spier RE, Griffiths JB, Berthold W, editors. Animal cell technology: Butterworth-Heinemann; 1994. p. 735-7. Available from: http://www. sciencedirect.com/science/article/pii/B9780750618458501629. Cited 2020 Mar 24.

125. Lamers CHJ, Gratama JW, Luider-Vrieling B, Bolhuis RLH, Bast EJEG. Largescale production of natural cytokines during activation and expansion of human $T$ lymphocytes in hollow fiber bioreactor cultures. J Immunother. 1999;22(4):299-307.

126. Liu Z, Wong JT. Proliferative and regenerative capacities of CD4+ T cells upon TCR stimulation. Clin Immunol. 1999;93(1):16-23.

127. Trickett AE, Kwan YL, Cameron B, Dwyer JM. Ex vivo expansion of functional T lymphocytes from HIV-infected individuals. J Immunol Methods. 2002; 262(1-2):71-83.

128. Curcio E, Piscioneri A, Salerno S, Tasselli F, Morelli S, Drioli E, et al. Human lymphocytes cultured in 3-D bioreactors: influence of configuration on metabolite transport and reactions. Biomaterials. 2012;33(33):8296-303.

129. Lewko WM, Good RW, Bowman D, Smith TL, Oldham RK. Growth of tumor derived activated T-cells for the treatment of cancer. Cancer Biother. 1994; 9(3):211-24

130. Freedman RS, Kudelka AP, Kavanagh JJ, Verschraegen C, Edwards CL, Nash $M$, et al. Clinical and biological effects of intraperitoneal injections of recombinant interferon-gamma and recombinant interleukin 2 with or without tumor-infiltrating lymphocytes in patients with ovarian or peritoneal carcinoma. Clin Cancer Res Off J Am Assoc Cancer Res. 2000;6(6): 2268-78.

131. Stroncek DF, Tran M, Frodigh SE, David-Ocampo V, Ren J, Larochelle A, et al. Preliminary evaluation of a highly automated instrument for the selection of CD34+ cells from mobilized peripheral blood stem cell concentrates. Transfusion (Paris). 2016;56(2):511-7.
132. Klapper JA, Thomasian AA, Smith DM, Gorgas GC, Wunderlich JR, Smith FO, et al. Single-pass, closed-system rapid expansion of lymphocyte cultures for adoptive cell therapy. J Immunol Methods. 2009;345(1-2):90-9.

133. Goltry KL, Hampson BS, Venturi NA, Bartel RL. Large-scale production of adult stem cells for clinical use. In: Emerging technology platforms for stem cells: Wiley; 2009. p. 153-68. Available from: https://onlinelibrary.wiley.com/ doi/abs/10.1002/9780470454923.ch9. Cited 2020 Mar 30.

134. Guardino AE, Rajapaksa R, Ong KH, Sheehan K, Levy R. Production of myeloid dendritic cells (DC) pulsed with tumor-specific idiotype protein for vaccination of patients with multiple myeloma. Cytotherapy. 2006;8(3):27789.

135. Schlegel $P$, Lang A-M, Matela M, Horrer A, Schilling A, Jöchner A, et al. Ex vivo expansion of autologous, donor-derived NK-, $\gamma \delta \mathrm{T}-$, and cytokine induced killer (CIK) cells post haploidentical hematopoietic stem cell transplantation results in increased antitumor activity. Bone Marrow Transplant. 2019;54:727-32.

136. Kuzin I, Sun H, Moshkani S, Feng C, Mantalaris A, Wu JD, et al. Long-term immunologically competent human peripheral lymphoid tissue cultures in a 3D bioreactor. Biotechnol Bioeng. 2011;108(6):1430-40.

137. Giese C, Demmler CD, Ammer R, Hartmann S, Lubitz A, Miller L, et al. A human lymph node in vitro--challenges and progress. Artif Organs. 2006; 30(10):803-8.

138. Gilbertson JA, Sen A, Behie LA, Kallos MS. Scaled-up production of mammalian neural precursor cell aggregates in computer-controlled suspension bioreactors. Biotechnol Bioeng. 2006;94(4):783-92.

139. Foster AE, Forrester K, Gottlieb DJ, Barton GW, Romagnoli JA, Bradstock KF. Large-scale expansion of Cytomegalovirus-specific cytotoxic T cells in suspension culture. Biotechnol Bioeng. 2004;85(2):138-46.

140. Bohnenkamp H, Hilbert U, Noll T. Bioprocess development for the cultivation of human T-lymphocytes in a clinical scale. Cytotechnology. 2002;38(1-3):135-45

141. Hu W, Berdugo C, Chalmers JJ. The potential of hydrodynamic damage to animal cells of industrial relevance: current understanding. Cytotechnology. 2011;63(5):445-60.

142. Ramsborg CG, Windgassen D, Fallon JK, Paredes CJ, Papoutsakis ET. Molecular insights into the pleiotropic effects of plasma on ex vivoexpanded T cells using DNA-microarray analysis. Exp Hematol. 2004;32(10): 970-90.

143. Foster AE, Forrester K, Li Y-C, Gottlieb DJ. Ex-vivo uses and applications of cytokines for adoptive immunotherapy. Curr Pharm Des. 2004;10(11):1207-20.

144. Hilbert U, Jelinek N, Schmidt S, Biselli M. Bioprocess development for the cultivation of human T-lymphocytes. Eng Life Sci. 2001;1(1):20-3.

145. Carswell KS, Weiss JW, Papoutsakis ET. Low oxygen tension enhances the stimulation and proliferation of human T lymphocytes in the presence of IL2. Cytotherapy. 2000;2(1):25-37.

146. Krieger JA, Landsiedel JC, Lawrence DA. Differential in vitro effects of physiological and atmospheric oxygen tension on normal human peripheral blood mononuclear cell proliferation, cytokine and immunoglobulin production. Int J Immunopharmacol. 1996;18(10):545-52.

147. Collins PC, Nielsen LK, Patel SD, Papoutsakis ET, Miller WM. Characterization of hematopoietic cell expansion, oxygen uptake, and glycolysis in a controlled, stirred-tank bioreactor system. Biotechnol Prog. 1998;14(3):466-72.

148. Collins PC, Miller WM, Papoutsakis ET. Stirred culture of peripheral and cord blood hematopoietic cells offers advantages over traditional static systems for clinically relevant applications. Biotechnol Bioeng. 1998:59(5):534-43.

149. Hosseinizand H, Ebrahimi M, Abdekhodaie MJ. Agitation increases expansion of cord blood hematopoietic cells and promotes their differentiation into myeloid lineage. Cytotechnology. 2016;68(4):969-78.

150. De león A, Mayani H, Ramírez OT. Design, characterization and application of a minibioreactor for the culture of human hematopoietic cells under controlled conditions. Cytotechnology. 1998;28(1-3):127-38.

151. Li Q, Liu Q, Cai H, Tan W-S. A comparative gene-expression analysis of CD34+ hematopoietic stem and progenitor cells grown in static and stirred culture systems. Cell Mol Biol Lett. 2006;11(4):475-87.

152. Kaiser $P$, Werner $M$, Jérôme $V$, Freitag $R$. Scale-up of the ex vivo expansion of encapsulated primary human T lymphocytes. Biotechnol Bioeng. 2018; 115(10):2632-42.

153. Barton G, Forrester K, Bradstock K, Gottlieb D, Foster A. Optimizing bioreactor productivity for therapeutic immune cells. Food Bioprod Process. 2005:83(2 C):158-63. 
154. Bajgain P, Mucharla R, Wilson J, Welch D, Anurathapan U, Liang B, et al. Optimizing the production of suspension cells using the G-Rex " $\mathrm{M}$ " series. Mol Ther - Methods Clin Dev. 2014;1:14015.

155. Bajgain P, Tawinwung S, D'Elia L, Sukumaran S, Watanabe N, Hoyos V, et al. CAR T cell therapy for breast cancer: harnessing the tumor milieu to drive $T$ cell activation. J Immunother Cancer. 2018:6(1):34.

156. Pampusch MS, Haran KP, Hart GT, Rakasz EG, Rendahl AK, Berger EA, et al. Rapid transduction and expansion of transduced T cells with maintenance of central memory populations. Mol Ther Methods Clin Dev. 2020;16:1-10.

157. Ludwig J, Hirschel M. Methods and process optimization for large-scale CAR T expansion using the G-Rex cell culture platform. Methods Mol Biol Clifton NJ. 2020;2086:165-77.

158. Vera JF, Brenner LJ, Gerdemann U, Ngo MC, Sili U, Liu H, et al. Accelerated production of antigen-specific $T$ cells for preclinical and clinical applications using gas-permeable rapid expansion cultureware (G-Rex). J Immunother. 2010;33(3):305-15.

159. Forget M-A, Haymaker C, Dennison JB, Toth C, Maiti S, Fulbright OJ, et al. The beneficial effects of a gas-permeable flask for expansion of tumorinfiltrating lymphocytes as reflected in their mitochondrial function and respiration capacity. Oncoimmunology. 2016;5(2):e1057386.

160. Orio J, Carli C, Janelle V, Giroux M, Taillefer J, Goupil M, et al. Early exposure to interleukin-21 limits rapidly generated anti-Epstein-Barr virus T-cell line differentiation. Cytotherapy. 2015;17(4):496-508.

161. Rooney CM, Leen AM, Vera JF, Heslop HE. T lymphocytes targeting native receptors. Immunol Rev. 2014;257(1) Available from: https://www.ncbi.nlm. nih.gov/pmc/articles/PMC3869095/. Cited 2019 Dec 7.

162. Gagliardi C, Khalil M, Foster AE. Streamlined production of genetically modified T cells with activation, transduction and expansion in closedsystem G-Rex bioreactors. Cytotherapy. 2019;21(12):1246-57.

163. Spielmann G, Bollard CM, Kunz H, Hanley PJ, Simpson RJ. A single exercise bout enhances the manufacture of viral-specific T-cells from healthy donors: implications for allogeneic adoptive transfer immunotherapy. Sci Rep. 2016; 6:25852.

164. Leen AM, Bollard CM, Mendizabal AM, Shpall EJ, Szabolcs P, Antin JH, et al. Multicenter study of banked third-party virus-specific T cells to treat severe viral infections after hematopoietic stem cell transplantation. Blood. 2013; 121(26):5113-23.

165. Dave H, Luo M, Blaney JW, Patel S, Barese C, Cruz CR, et al. Toward a rapid production of multivirus-specific T cells targeting BKV, adenovirus, CMV, and EBV from umbilical cord blood. Mol Ther Methods Clin Dev. 2017;5:13-21.

166. Gerdemann U, Vera JF, Rooney CM, Leen AM. Generation of multivirusspecific T cells to prevent/treat viral infections after allogeneic hematopoietic stem cell transplant. J Vis Exp. 2011;51:e2736.

167. Horlock C, Skulte A, Mitra A, Stansfield A, Bhandari S, Ip W, et al. Manufacture of GMP-compliant functional adenovirus-specific T-cell therapy for treatment of post-transplant infectious complications. Cytotherapy. 2016; 18(9):1209-18.

168. Luah YH, Sundar Raj K, Koh MBC, Linn YC. A novel simplified method of generating cytomegalovirus-specific cytokine-induced killer cells of high specificity and superior potency with GMP compliance. Clin Immunol. 2019; 205:83-92.

169. Nakazawa Y, Huye LE, Salsman VS, Leen AM, Ahmed N, Rollins L, et al. PiggyBac-mediated Cancer immunotherapy using EBV-specific cytotoxic Tcells expressing HER2-specific chimeric antigen receptor. Mol Ther. 2011; 19(12):2133-43.

170. Murad JM, Baumeister SH, Werner L, Daley H, Trébéden-Negre H, Reder J, et al. Manufacturing development and clinical production of NKG2D chimeric antigen receptor-expressing T cells for autologous adoptive cell therapy. Cytotherapy. 2018;20(7):952-63.

171. Parlar A, Sayitoglu EC, Ozkazanc D, Georgoudaki A-M, Pamukcu C, Aras M, et al. Engineering antigen-specific NK cell lines against the melanomaassociated antigen tyrosinase via TCR gene transfer. Eur J Immunol. 2019; 49(8):1278-90.

172. Sakellariou-Thompson D, Forget M-A, Hinchcliff E, Celestino J, Hwu P, Jazaeri AA, et al. Potential clinical application of tumor-infiltrating lymphocyte therapy for ovarian epithelial cancer prior or post-resistance to chemotherapy. Cancer Immunol Immunother. 2019;68(11):1747-57.

173. Chakraborty R, Mahendravada A, Perna SK, Rooney CM, Heslop HE, Vera JF, et al. Robust and cost effective expansion of human regulatory $T$ cells highly functional in a xenograft model of graft-versus-host disease. Haematologica. 2013;98(4):533-7.
174. Gerdemann U, Katari UL, Papadopoulou A, Keirnan JM, Craddock JA, Liu H, et al. Safety and clinical efficacy of rapidly-generated trivirus-directed T cells as treatment for adenovirus, EBV, and CMV infections after allogeneic hematopoietic stem cell transplant. Mol Ther. 2013;21(11):2113-21.

175. Ramanayake S, Bilmon I, Bishop D, Dubosq M-C, Blyth E, Clancy L, et al. Low-cost generation of Good manufacturing practice-grade CD19-specific chimeric antigen receptor-expressing T cells using piggyBac gene transfer and patient-derived materials. Cytotherapy. 2015;17(9):1251-67.

176. Jin J, Gkitsas N, Fellowes VS, Ren J, Feldman SA, Hinrichs CS, et al. Enhanced clinical scale manufacturing of TCR transduced T-cells using closed culture system modules. J Transl Med. 2018;16(1):13.

177. Kuranda K, Caillat-Zucman S, You S, Mallone R. In vitro expansion of antiviral T cells from cord blood by accelerated co-cultured dendritic cells. Mol Ther - Methods Clin Dev. 2019;13:112-20.

178. Xiao L, Chen C, Li Z, Zhu S, Tay JC, Zhang X, et al. Large-scale expansion of Vy9V82 T cells with engineered K562 feeder cells in G-Rex vessels and their use as chimeric antigen receptor-modified effector cells. Cytotherapy. 2018; 20(3):420-35.

179. Shah N, Martin-Antonio B, Yang H, Ku S, Lee DA, Cooper LJN, et al. Antigen presenting cell-mediated expansion of human umbilical cord blood yields log-scale expansion of natural killer cells with anti-myeloma activity. PLoS One. 2013;8(10):e76781.

180. Jin J, Sabatino M, Somerville R, Wilson JR, Dudley ME, Stroncek DF, et al. Simplified method of the growth of human tumor infiltrating lymphocytes in gas-permeable flasks to numbers needed for patient treatment. J Immunother. 2012;35(3):283-92.

181. Forget M-A, Malu S, Liu H, Toth C, Maiti S, Kale C, et al. Activation and propagation of tumor infiltrating lymphocytes on clinical-grade designe artificial antigen presenting cells for adoptive immunotherapy of melanoma. J Immunother Hagerstown Md 1997. 2014;37(9):448-60.

182. Bollard CM, Gottschalk S, Huls MH, Leen AM, Gee AP, Rooney CM. Manufacture of GMP-grade cytotoxic T lymphocytes specific for LMP1 and LMP2 for patients with EBV-associated lymphoma. Cytotherapy. 2011;13(5): $518-22$.

183. Sili U, Leen AM, Vera JF, Gee AP, Huls H, Heslop HE, et al. Production of good manufacturing practice-grade cytotoxic T lymphocytes specific for Epstein-Barr virus, cytomegalovirus and adenovirus to prevent or treat viral infections post-allogeneic hematopoietic stem cell transplant. Cytotherapy. 2012;14(1):7-11.

184. Hanley PJ, Lam S, Shpall EJ, Bollard CM. Expanding cytotoxic T lymphocytes from umbilical cord blood that target cytomegalovirus, Epstein-Barr virus, and adenovirus. J Vis Exp. 2012;63:e3627.

185. Lapteva N, Parihar R, Rollins LA, Gee AP, Rooney CM. Large-scale culture and genetic modification of human natural killer cells for cellular therapy. Methods Mol Biol. 2016;1441:195-202.

186. Wickström S, Lövgren T. Expansion of tumor-infiltrating lymphocytes from melanoma tumors. Methods Mol Biol. 2019;1913:105-18.

187. Mock U, Nickolay L, Philip B, Cheung GW-K, Zhan H, Johnston ICD, et al. Automated manufacturing of chimeric antigen receptor $T$ cells for adoptive immunotherapy using CliniMACS prodigy. Cytotherapy. 2016;18(8):1002-11.

188. Oberschmidt O, Morgan M, Huppert V, Kessler J, Gardlowski T, Matthies N, et al. Development of automated separation, expansion, and quality control protocols for clinical-scale manufacturing of primary human NK cells and Alpharetroviral chimeric antigen receptor engineering. Hum Gene Ther Methods. 2019;30(3):102-20.

189. Spohn G, Wiercinska E, Karpova D, Bunos M, Hümmer C, Wingenfeld E, et al. Automated CD34+ cell isolation of peripheral blood stem cell apheresis product. Cytotherapy. 2015;17(10):1465-71.

190. Hümmer C, Poppe C, Bunos M, Stock B, Wingenfeld E, Huppert V, et al, Automation of cellular therapy product manufacturing: results of a split validation comparing CD34 selection of peripheral blood stem cell apheresis product with a semi-manual vs. an automatic procedure. J Transl Med. 2016;14(1):76.

191. Bunos M, Hümmer C, Wingenfeld E, Sorg N, Pfirrmann V, Bader P, et al. Automated isolation of primary antigen-specific $T$ cells from donor lymphocyte concentrates: results of a feasibility exercise. Vox Sang. 2015; 109(4):387-93.

192. Kumaresan P, Figliola M, Moyes JS, Huls MH, Tewari P, Shpall EJ, et al. Automated cell enrichment of cytomegalovirus-specific T cells for clinical applications using the cytokine-capture system. J Vis Exp. 2015;2015(104): 52808. 
193. Priesner C, Esser R, Tischer S, Marburger M, Aleksandrova K, Maecker-Kolhoff $B$, et al. Comparative analysis of clinical-scale IFN- $\gamma$-positive T-cell enrichment using partially and fully integrated platforms. Front Immunol. 2016;7:393.

194. Kállay K, Kassa C, Réti M, Karászi É, Sinkó J, Goda V, et al. Early experience with CliniMACS prodigy CCS (IFN-gamma) system in selection of virusspecific $T$ cells from third-party donors for pediatric patients with severe viral infections after hematopoietic stem cell transplantation. J Immunother. 2018;41(3):158-63.

195. Kim E-K, Ahn Y-O, Kim S, Kim TM, Keam B, Heo DS. Ex vivo activation and expansion of natural killer cells from patients with advanced cancer with feeder cells from healthy volunteers. Cytotherapy. 2013;15(2):231-241.e1.

196. Klöß S, Oberschmidt O, Morgan M, Dahlke J, Arseniev L, Huppert V, et al. Optimization of human NK cell manufacturing: fully automated separation, improved ex vivo expansion using IL-21 with autologous feeder cells, and generation of anti-CD123-CAR-expressing effector cells. Hum Gene Ther. 2017:28(10):897-913.

197. Zhu F, Shah N, Xu H, Schneider D, Orentas R, Dropulic B, et al. Closedsystem manufacturing of CD19 and dual-targeted CD20/19 chimeric antigen receptor T cells using the CliniMACS prodigy device at an academic medical center. Cytotherapy. 2018;20(3):394-406.

198. Granzin M, Soltenborn S, Müller S, Kollet J, Berg M, Cerwenka A, et al. Fully automated expansion and activation of clinical-grade natural killer cells for adoptive immunotherapy. Cytotherapy. 2015;17(5):621-32.

199. Priesner C, Aleksandrova K, Esser R, Mockel-Tenbrinck N, Leise J, Drechsel K, et al. Automated enrichment, transduction, and expansion of clinical-scale CD62L ${ }^{+} \mathrm{T}$ cells for manufacturing of gene therapy medicinal products. Hum Gene Ther. 2016;27(10):860-9.

200. Lock D, Mockel-Tenbrinck N, Drechsel K, Barth C, Mauer D, Schaser T, et al. Automated manufacturing of potent CD20-directed chimeric antigen receptor T cells for clinical use. Hum Gene Ther. 2017;28(10):914-25.

201. Blaeschke F, Stenger D, Kaeuferle T, Willier S, Lotfi R, Kaiser AD, et al. Induction of a central memory and stem cell memory phenotype in functionally active CD4+ and CD8+ CAR T cells produced in an automated good manufacturing practice system for the treatment of CD19+ acute lymphoblastic leukemia. Cancer Immunol Immunother. 2018;67(7):1053-66.

202. Zhang W, Jordan KR, Schulte B, Purev E. Characterization of clinical grade CD19 chimeric antigen receptor $T$ cells produced using automated CliniMACS prodigy system. Drug Des Devel Ther. 2018;12:3343-56.

203. Aleksandrova K, Leise J, Priesner C, Melk A, Kubaink F, Abken H, et al. Functionality and cell senescence of CD4/ CD8-selected CD20 CAR T cells manufactured using the automated CliniMACS prodigy ${ }^{\oplus}$ platform. Transfus Med Hemother. 2019;46(1):47-54.

204. Fernández L, Fernández A, Mirones I, Escudero A, Cardoso L, Vela M, et al. GMP-compliant manufacturing of NKG2D CAR memory T cells using CliniMACS prodigy. Front Immunol. 2019;10 Available from: https://www. ncbi.nlm.nih.gov/pmc/articles/PMC6795760/. Cited 2019 Dec 5.

205. Marín Morales JM, Münch N, Peter K, Freund D, Oelschlägel U, Hölig K, et al. Automated clinical grade expansion of regulatory $T$ cells in a fully closed system. Front Immunol. 2019;10:38.

\section{Publisher's Note}

Springer Nature remains neutral with regard to jurisdictional claims in published maps and institutional affiliations.

Ready to submit your research? Choose BMC and benefit from:
- fast, convenient online submission
- thorough peer review by experienced researchers in your field
- rapid publication on acceptance
- support for research data, including large and complex data types
- gold Open Access which fosters wider collaboration and increased citations
- maximum visibility for your research: over 100M website views per year
At BMC, research is always in progress.
Learn more biomedcentral.com/submissions

